\title{
O LIXO ENQUADRADO NUM CENÁRIO EM MOVIMENTO: RELATO DE CAMPO ETNOGRÁFICO COM IMAGENS NA HOLANDA
}

\author{
Carla Pires Vieira da Rocha ${ }^{1}$
}

Entulho, tudo o que não presta e se joga fora, coisas inúteis, velhas e sem valor, sujeira (Ferreira, 1987), resto que não se aproveita, imundície (Houaiss e Villar, 2009). As definições de lixo que encontramos nos dicionários são categóricas ao atribuir um sentido quase irrevogável aos objetos que descartamos, indicando um destino praticamente sem volta. Mas o que descartamos nem sempre tem um destino final. $\mathrm{O}$ que passa a ser considerado "lixo", além de ser passível de adquirir novos significados, pode consistir em um meio de nos revelar aspectos do próprio contexto onde é produzido. Baseado em uma experiência etnográfica realizada a partir de imagens em Amstelveen (Países Baixos), o objetivo deste relato é abordar possíveis ressignificações relacionadas ao que comumente é concebido como "lixo", levando em conta o acirramento das problemáticas associadas à produção de resíduos sólidos e também aspectos culturais do período atual da globalização, em especial, os que dizem respeito à circulação mais intensa de pessoas. ${ }^{2}$

O relato decorre de minha pesquisa de doutorado, cujo trabalho de campo foi realizado nos Países Baixos, no período de um ano, entre 2015 e 2016. As imagens foram obtidas durante os meses em que residi em Uilenstede, o campus universitário da VU (Vrije Universiteit Amsterdam), situado em Amstelveen, município que compõe a área metropolitana de Amsterdã, capital do país. Essas imagens resultam de questionamentos surgidos a partir do trabalho de campo que realizei, em que a temática do lixo também esteve presente, enfocada através de aspectos envolvendo consumo, migrações e globalização.

1 Universidade Federal de Santa Catarina, Brasil. Email: carlapvrocha@gmail.com ORCID id: https://orcid.org/0000-0003-2457-4634

2 O presente trabalho foi realizado com apoio da Coordenação de Aperfeiçoamento de Pessoal de Nível Superior - Brasil (CAPES) - Código de Financiamento 001. 


\section{O lixo em um contexto demarcado por movimentos intensos}

O lixo tem sido apontado como um problema de proporções cada vez maiores e com consequências em escala global. Sociedades industrializadas e marcadas pelo consumo intensivo são consideradas as responsáveis pela maior geração de resíduos. Segundo dados da Organização das Nações Unidas (ONU), anualmente, são produzidas mais de 2 bilhões de toneladas de resíduos no mundo ${ }^{3}$. Não é novidade que, além do apelo generalizado ao consumo, a intensificação da produção de determinados bens também decorre da sua obsolescência programada, potencializando uma geração inesgotável de resíduos. Ainda de acordo com a ONU, 99\% dos produtos comprados no mundo são descartados dentro de seis meses ${ }^{4}$.

Tanto a geração de resíduos quanto a sua gestão variam de um contexto para o outro. Além de refletirem hábitos de consumo das sociedades, os resíduos também abarcam a mobilização de significados atribuídos a esses resíduos/“lixo”, ressoando nas ações ligadas ao seu descarte e também à sua apropriação. Essas ações também resultam de diferentes motivações. Se enfocarmos no exemplo dos contentores do campus da VU (Vrije Universiteit Amsterdam), a mobilização que ocorre em torno daqueles objetos está diretamente relacionada à grande circulação de pessoas naquele contexto, refletindo a dinâmica migratória que caracteriza não apenas o campus universitário, mas também o país.

A Holanda é um país de movimentos migratórios intensos. Tais movimentos não consistem em algo propriamente recente, uma vez que perfazem a trajetória histórica desse país ${ }^{5}$. No caso de Amsterdã, as regiões de onde provêm os imigrantes têm se diversificado e, diferente de qualquer outro momento no passado, a imigração tem agora um alcance mais global (Castles e Miller, 1993). Os fluxos atuais podem ser atribuídos a diferentes fatores. O país é considerado um dos mais bem avaliados no quadro global em termos de qualidade de vida e de crescimento econômico, dado o seu alto índice de desenvolvimento humano (IDH), atraindo assim muitos imigrantes em busca de

3 Disponível em: https://nacoesunidas.org/humanidade-produz-mais-de-2-bilhoes-de-toneladas-de-lixopor-ano-diz-onu-em-dia-mundial/ Acesso em: 10 set. 2020.

4 Disponível em: https://nacoesunidas.org/humanidade-produz-mais-de-2-bilhoes-de-toneladas-de-lixopor-ano-diz-onu-em-dia-mundial/ Acesso em: 10 set. 2020.

5 O país também é reconhecido por seu papel importante no que se refere ao comércio internacional e à circulação de mercadorias ao redor do mundo, sobretudo em virtude de sua localização estratégica. Através dos portos marítimos de Amsterdã e Rotterdam (o maior da Europa) e também do aeroporto de Schipoll, além de protagonizar a distribuição de muitos produtos de diversas espécies para toda a Europa, o país ainda é uma porta de entrada e saída de produtos que abastecem muitas outras partes do mundo. 
trabalho e melhoria de vida. A Holanda também é referência importante no que diz respeito ao âmbito educacional, concentrando universidades renomadas, o que motiva o deslocamento estudantes e pesquisadores de diversos países, incluindo o Brasil ${ }^{6}$. Além disso, alguns imaginários associados ao país como um local de tolerância, liberdade e diversidade cultural, corroboram para que se torne o destino de indivíduos do mundo inteiro.

Amsterdã, capital dos Países Baixos, é considerada um dos pólos migratórios mais significativos da Europa. O seu grande contingente de imigrantes é um dos fatores que contribui para sua denominação de cidade global, nos termos de Sassen (2010) ${ }^{7}$. De acordo com dados oficiais, o total de imigrantes chega a ser superior ao de holandeses ${ }^{8}$. Além de ser a cidade mais populosa dos Países Baixos, Amsterdã é a capital de um dos países com maior densidade populacional da Europa ${ }^{9}$

As pequenas dimensões do país e sua alta densidade populacional impuseram a necessidade de se priorizar ações visando a proteção ambiental. Especialmente nos últimos anos, a Holanda tem se tornado forte referência pelo avanço de medidas nessa área. $\mathrm{O}$ fato de concentrar um dos mais altos índices de coleta de lixo do mundo, com cerca de $80 \%$ de reciclagem é referido como exemplo significativo em tal direção (Schiettekatte e Bakker, 2017). Entretanto, apesar de seus esforços em nutrir uma imagem de pioneira em diversas políticas ambientais, entrevistas que realizei no trabalho de campo com residentes no país mostram que há uma série de críticas no que se refere a essas políticas, sobretudo a referente à gestão de resíduos, em particular, a ausência de contentores de lixo em diversos pontos de Amsterdã, a cidade mais populosa. Nessa mesma perspectiva, ainda é apontada a grande quantidade de embalagens descartáveis no comércio (consideradas desnecessárias por alguns sujeitos

6 Cabe observar que este texto resulta de um estágio de doutorado sanduíche realizado a partir do convênio CAPES/NUFFIC com a Universidade Federal de Santa Catarina, que vem possibilitando diversos intercâmbios de pesquisadores do Brasil na Holanda.

7 Para Sassen (2010), as cidades globais são aquelas em que múltiplos processos de âmbito global assumem formas concretas e localizadas. O caráter internacional das cidades globais não estaria apenas associado à sua infraestrutura de telecomunicações ou empresas internacionais, mas também aos muitos ambientes culturais onde onde os indivíduos circulam.

8 Computando imigrantes de primeira e segunda geração, cerca de 178 nacionalidades estariam representadas somente na cidade de Amsterdã. Fonte: My first month: all you need to know and note. Expatcenter Amsterdam, 11 ed. Jan, 2015.

9 Estimado em 508 habitantes por quilômetro quadrado, no ano de 2020. (Disponível em: https://www.worldometers.info/world-population/netherlands-population/ 07 set. 2020). Para se ter uma ideia do que isso representa, a Suíça, por exemplo, tem área total equivalente à Holanda, mas metade da sua população. Já a população de Amsterdã é estimada em 741.636 habitantes. Disponível em: https://www.worldometers.info/world-population/netherlands-population/Acesso em: 07 set. 2020 . 
entrevistados), em particular, no que diz respeito aos artigos alimentares das principais redes de supermercados do país.

Amstelveen é um dos oito municípios que compõe a área metropolitana de Amsterdã e é onde está situado Uilenstede, o campus da Vrije Universiteit Amsterdam. Com cerca de 3.400 residentes, é considerado o maior campus de estudantes do norte da Europa. A menos de $2 \mathrm{~km}$ distante da universidade, o campus está localizado em uma fronteira quase imperceptível entre Amstelveen e Amsterdã. Essa proximidade com a capital possibilita aos estudantes expandirem muitas das suas atividades cotidianas para esse centro urbano, a ponto de o campus ser percebido quase como uma extensão territorial de Amsterdã.

Embora a municipalidade seja a responsável pela coleta de lixo no campus, as regras de descarte são estabelecidas pela administração do condomínio. Uma dessas regras dita que, ao ser desocupado, o imóvel deve estar nas mesmas condições em que estava quando foi locado, ou seja, qualquer mobília ou utensílio que não conste no rol dos pertences do imóvel, deve ser retirado daquelas instalações, antes da devolução das chaves, não importando quais objetos sejam e nem mesmo seu estágio de conservação. Essas regras e também aquelas relativas a outras condutas a serem observadas dentro do campus ou mesmo informes diversos relacionados à residência no local são periodicamente enviadas através de mensagens de e-mail para os respectivos moradores.

\begin{abstract}
Vamos todos trabalhar juntos para manter o campus limpo! Você se vê diante de um recipiente de lixo cheio com um saco de lixo na mão? Experimente o próximo recipiente - esse ainda pode ter espaço. Se a fiscalização o pegar deixando lixo doméstico próximo ao contêiner, você será multado. Os agentes são muito bons em descobrir de onde vem o lixo e quem é o responsável por isso. Normalmente, eles saberão onde encontrar você. Isso seria um desperdício de dinheiro, especialmente após o caro período de férias.

Você também pode ser multado por despejar lixo muito grande, e os policiais costumam patrulhar à paisana. Evite ser multado e não jogue fora seu lixo grande até a noite antes do dia da coleta. O lixo pertence aos recipientes de lixo. Os sacos de lixo que se encontrarem na galeria do móvel ou nas escadas, serão retirados pelo zelador ou gerente às suas custas: serão deduzidos do reembolso da limpeza ${ }^{10}$.
\end{abstract}

10 Tradução livre da seguinte mensagem de e-mail: "Let's all work together to keep the campus clean!". "Do find yourself standing in front of a full waste container with a rubbish bag in your hand? Try the next container - that one might still have room. If enforcement catches you leaving household rubbish next to the container, you will be fined. The enforcers are very good at finding out where the refuse came from and who is responsible for it. Usually they will know where to find you. This would be a waste of your money, especially after the expensive holiday period". "You can also be fined for dumping oversized rubbish, and the enforcers usually patrol in plain clothes. Avoid getting fined and don't put out your oversized rubbish until the evening before the collection day". 
O tom ameaçador das mensagens acima enviadas por e-mail aos residentes pela administradora do campus indica como o descarte de lixo nesse local deve obedecer a regras bastante rígidas. Sugere ainda a existência de uma estrutura com relação ao lixo, tanto no que se refere ao descarte quanto à coleta. E, de fato, há contentores para diferentes categorias de resíduos em todas as áreas do campus, desde aqueles subterrâneos para papéis, vidros, cartões, plásticos, resíduos orgânicos, até os contentores maiores, situados em áreas específicas e destinados ao descarte de objetos de grandes dimensões como móveis, eletrodomésticos ou outros itens que não caibam nos contentores subterrâneos.

Os contentores de resíduos maiores estão distribuídos em número relativamente menor dentro do campus (seis) e se diferenciam dos demais também porque se configuram como áreas abertas, de livre circulação. Dessa forma, possibilitam que se possa não apenas visualizar o que foi descartado pelos residentes do campus, mas também a apropriação de muitos dos objetos ali depositados por diferentes indivíduos.

O campus da Vrije Universiteit Amsterdam é um local onde se reproduzem muitos movimentos migratórios, mesmo que se constituam como movimentos específicos e temporários. Na medida em que os contentores de resíduos refletem uma certa consonância entre o fluxo de objetos e o fluxo de pessoas, pode-se considerar que, a partir dessas áreas, é ressaltada a própria dinâmica da globalização vigente (Appadurai, 1996) ${ }^{11}$. Essa relação entre o movimento de coisas e de pessoas foi o que também fundamentou as imagens deste relato, conforme será abordado a seguir.

\section{Imagens e ressignificações do "lixo"}

As imagens que compõem este relato foram obtidas na área que integra os prédios residenciais no campus da Vrije Universiteit Amsterdam (VU), onde residi na Holanda. Conforme foi mencionado acima, a maior parte dos moradores do campus era constituída por estudantes e pesquisadores de diversas nacionalidades. A área em questão era próxima ao edifício em que eu residia e era onde estava situado um dos seis contentores destinados a resíduos de grandes proporções distribuídos pelo campus.

Os objetos que ali eram depositados compreendiam desde embalagens de plástico e papelão ou partes de móveis que haviam sido desmontados, até itens como frigobar, geladeira, sofás, colchões, louças, panelas, talheres e elétricos de cozinha,

11 Appadurai (1996), ao sinalizar um caminho para se compreender a globalização em suas dimensões culturais, ainda inclui como característica desse período a intensificação crescente dos fluxos de capital, ideias, informações e tecnologias em escala transnacional. 
bicicletas, cadeiras, eletrônicos, isto é, diversos objetos que certamente já haviam cumprido uma determinada função dentro de algumas daquelas residências, participando assim da vida cotidiana de alguns moradores. Aqueles objetos encontravam-se em diferentes estágios de conservação; alguns eram notadamente mais novos e, portanto, reaproveitáveis em sua integralidade; outros pareciam já bastante danificados, indicando não ter mais o mesmo proveito.

Minha vista dessa área era privilegiada, pois eu morava no terceiro andar do edifício e podia acompanhar toda a movimentação que ocorria naquele contentor. Ao observar inicialmente aquele espaço, era como se estivesse diante de um quadro que, periodicamente, ia assumindo formas distintas, dependendo do que ali era descartado ou coletado. Um quadro em cores, cujas linhas, formas e volumes eram configurados a partir de uma palheta construída pelo consumo e descarte.

Meu interesse inicial em capturar aquele quadro através de imagens se baseava em uma relação anterior com a fotografia, moldada pela minha formação acadêmica em artes visuais. Meu objetivo primeiro era apreender aqueles objetos em imagem tentando abstrai-los do seu entorno, através de uma teleobjetiva, explorando sua potencialidade estética e visual. Mas, à medida que passei a observar o movimento de pessoas naquele local e perceber que aquela configuração - formas intercaladas com espaços vazios que logo eram preenchidos com outras formas - resultava do fluxo de pessoas, dos gestos de indivíduos anônimos, em trânsito, a fotografia também passou a significar a possibilidade de construção de uma narrativa em torno de algumas perguntas e para as quais eu não tinha respostas: a quais outras histórias e memórias haviam se prestado? a quem haviam pertencido? quem eram aqueles sujeitos? Assim, capturar o que ocorria naquele contentor/cenário através da fotografia, a princípio, consistia em uma tentativa de registrar rastros de vida que carregavam aquelas coisas.

As coisas tem uma vida social e seus significados estão inscritos em suas formas, seus usos, suas trajetórias, defende Appadurai (2008). A única certeza é de que naquelas coisas habitavam traços de vida e significado deixados por personagens temporários, migrantes, cujo desapego imposto pela efemeridade do período de residência naquele local, não permitia prolongar ou até mesmo eternizar um determinado valor e significado a qualquer daqueles itens. Marcadas assim por uma história temporária no/nos ambiente(s) em que haviam habitado anteriormente, aquelas coisas agora compunham uma museografia do acaso, sujeita a intervenções a qualquer 
tempo, sendo assim também passíveis de ganhar novas significações pelas mãos de outros personagens.

Portanto, através da janela de minha residência, o meu olhar distanciado fisicamente daquele quadro e, ao mesmo tempo, aproximado por uma teleobjetiva, também refletia uma certa ambiguidade com relação à minha percepção daqueles objetos. Se, inicialmente, apenas instigavam à criação de imagens pelas suas formas, cores e volume, à medida que passei a observar mais regularmente aquele cenário e as movimentações que ali ocorriam, o foco foi voltado para um exercício narrativo, idealizando conferir uma certa memória (imaginada) àquelas coisas distanciadas, marcadas pela efemeridade, que também se ofereciam à representação de um mundo possivel $^{12}$.

Mesmo que anônimas, aquelas coisas haviam composto ambientes, outros cenários. Se, de certa forma, sinalizavam para os movimentos intensos de pessoas que vêm demarcando a época atual e a correlativa diversidade étnica e cultural que perfazia a paisagem urbana a partir daquele campus, essas coisas também abarcavam mobilidade pelas mãos de indivíduos que circulavam por aquele entorno: o casal de jovens que hesitou antes de se decidir por levar uma pequena mesa; o senhor de cabelos brancos que mais de uma vez desmontou algum eletrodoméstico para levar consigo somente o motor; o jovem que descartou ali uma cadeira; a menina que depois de deixar ali um colchão, trouxe algumas almofadas; o senhor, que passava de bicicleta, revirou alguns objetos, mas levou somente uns poucos utensílios de cozinha. Diante daquele movimento das pessoas e das coisas, a noção de permanência somente parecia existir a partir das imagens que eu capturava.

\section{Um cenário de lixo no norte global}

O cenário de "lixo" que representava o contentor próximo à janela de minha residência no campus da VU, ao mesmo tempo em que me motivava à construção de narrativas visuais, acenava para a possibilidade de uma reflexão relativa a concepções de "lixo" em sociedades industrializadas do Norte Global, sobretudo no que dizia respeito ao desperdício, ao desígnio à morte de muitos objetos que podiam ainda ser considerados de vida útil em contextos que iam muito além daquele campus.

12 Ver Dubois, Philippe. Da imagem-traço à imagem-ficção: O movimento das teorias da fotografia de 1980 aos nossos dias. Tradução: Henrique Codato e Leonardo Gomes Pereira. In: discursos fotográficos, Londrina, v.13, n.22, p.31-51, jan./jul. 2017. 
Diversas vezes em que chegava diante da janela de minha moradia presenciava alguma ação dentro daquele espaço, fosse o descarte ou apropriação de algum objeto por parte de outros moradores, ou mesmo o reaproveitamento de partes/peças desmembradas daqueles objetos por transeuntes. Através da janela, acompanhava ainda o que parecia ser um destino fatal daqueles objetos - o seu recolhimento pelo caminhão de lixo da municipalidade, que ocorria três vezes por semana. Nesses dias, aquele cenário era totalmente esvaziado, não restando qualquer chance para uma possível utilidade posterior de algum daqueles objetos, não lhes era oferecida qualquer sobrevida.

À medida que passei a acompanhar mais seguidamente aquele cenário com a intenção de capturar em imagens as mudanças que ali ocorriam e de não deixar escapar o registro de algumas das composições que ali se configuravam, comecei a identificar alguns objetos que eventualmente poderiam me ser úteis, pois o apartamento em que eu residia somente contava com uma mobília básica. Assim, ao longo dos primeiros meses de residência no campus, fui complementando a mobília de minha moradia com diversos itens que passei a coletar naquele contentor: almofadas, colchões, cadeiras para escritório e para a sala, bem como diversos utensílios de cozinha (grill, panelas, talheres, recipientes).

Quando identificava algum desses objetos através da janela, descia rapidamente as escadas para coletá-lo, antes que fosse apropriado por alguém e também para garantir que a chuva não o danificasse, considerando o clima bastante instável na Holanda. Essa atividade de coleta já havia se transformado em uma espécie de um autodesafio, já que envolvia descer três andares do edifício rapidamente para logo retornar pelas mesmas escadas - pois não havia elevador - com algum objeto, cujo peso ou tamanho, muitas vezes, estava quase no limite das minhas forças. A rapidez também se devia ao fato daquela ação me parecer um pouco estranha, que soava quase como uma transgressão, já que, a princípio, nenhum daqueles objetos havia sido destinado a mim propriamente.

Se a apropriação dos itens disponíveis naquele contentor visava maior conforto no ambiente onde eu residia, significava ainda o exercício de uma outra relação com o consumo, baseada sobretudo em uma ideia de circularidade, isto é, aquele exercício consistia em uma possibilidade de reaproveitar aqueles objetos, prolongando sua vida útil. Tinha noção de que esse reaproveitamento, de certa forma, acarretava reordenar a 
linearidade que caracteriza o modelo de consumo e descarte, sobretudo de contextos mais favorecidos economicamente, e vem ocasionando o acirramento da problemática ambiental vigente. Esse exercício de apropriação daqueles objetos, portanto, também consistia em uma possibilidade de reflexão sobre o desperdício relacionado àquele "lixo", caso não fosse apropriado por alguém.

Tudo o que constava nos contentores do campus era periodicamente retirado pelo caminhão do lixo, sem haver distinção. Já é sabido que o lixo vem se tornando uma preocupação crescente em nível mundial. Dados da $\mathrm{ONU}^{13}$ É interessante lembrar que um dos objetivos da ONU (Organização das Nações Unidas) para o desenvolvimento sustentável está voltado para o implemento de padrões de produção e de consumo sustentáveis, com a meta de se diminuir a geração de resíduos por meio da prevenção, redução, reciclagem e reuso ${ }^{14}$. Os objetos ainda úteis descartados no espaço do campus, quando não apropriados por alguém, eram o retrato de um desperdício, cujas consequências, são correntemente associadas ao acirramento das problemáticas ambientais, envolvendo sobretudo o emprego desordenado de energias e materiais não renováveis, a poluição do ar, das águas, dos solos, perda da biodiversidade, entre outros aspectos.

A observação da dinâmica que ocorria naquele espaço e o seu registro em imagens tinha também como propósito colocar em questão concepções de lixo, assim como o consumo em um contexto do Norte Global. Aquela podia ser vista como uma realidade mais específica do campus em questão, regido por normas também específicas da sua administração, que ocasionavam uma produção de resíduos muitas vezes desnecessária, ao determinar a retirada dos objetos excedentes naquelas moradias quando desocupadas. No entanto, essa realidade não deixava de provocar uma reflexão de um ponto de vista mais amplo a respeito do "lixo" em um país mais favorecido economicamente, em comparação a outros países em situação oposta, incluindo alguns de onde provinham moradores daquele campus.

Além disso, a ausência de diretrizes que contemplassem ou estimulassem um melhor aproveitamento daqueles objetos, sua gestão mais sustentável dentro do campus, de certa forma, contradizia a própria imagem que não apenas Amsterdã e sua área metropolitana, como também o país buscava ostentar, ao proclamar incisivamente suas

13 Disponível em: https://nacoesunidas.org/humanidade-produz-mais-de-2-bilhoes-de-toneladas-de-lixopor-ano-diz-onu-em-dia-mundial/ Acesso em: 10 set. 2020.

14 Disponível em: https://nacoesunidas.org/pos2015/ods12/ Acesso em: 08 jun. 2020. 
políticas ambientais crescentes, baseadas em noções de sustentabilidade e de economia circular $^{15}$. Cabe mencionar que tal contradição era também apontada por alguns imigrantes residentes no país, entrevistados no trabalho de campo, relativo à pesquisa de doutorado realizada, ao colocarem em questão a efetividade de algumas políticas ambientais no país, especialmente as relativas à gestão de resíduos ${ }^{16}$.

A observação dos objetos descartados nos contentores de resíduos do campus da VU também possibilitava compreender o quanto a definição de "lixo" é atravessada por aspectos culturais, não resultando obrigatoriamente de uma condição objetiva da cultura material, mas acima de tudo de uma condição subjetiva. Seguindo a ótica de Mary Douglas (1991), o lixo não é uma categoria fixa de coisas, mas sim algo que resulta de classificação e relações. Em países mais favorecidos, como é o caso da Holanda, o lixo não consiste necessariamente em algo que perdeu seu valor utilitário, mas em algo que passou a ser definido como sem valor, ou seja, as condições sob as quais o lixo é compreendido são culturalmente determinadas (Thompson, 2017) ${ }^{17}$.

Assim, aquelas coisas que não se conformavam necessariamente como "lixo", que não apenas advinham do movimento de pessoas naquele ambiente universitário, mas também perfaziam movimentos através do seu descarte, reaproveitamento, reciclagem, adquiriam significados também móveis, temporários. Se o exemplo do que ocorria a partir do interior dos contentores do campos da VU (Vrije Universiteit Amsterdam) evidencia que as coisas não estão necessariamente presas aos significados que lhes possam ser atribuídos, ao mesmo tempo, não deixa dúvidas de que, em certas sociedades contemporâneas, as coisas cada vez mais se prestam à construção de imagens.

15 Tais políticas vêm ganhando notoriedade, principalmente, a partir de um programa implementado pelo governo holandês, voltado para o desenvolvimento de uma economia totalmente circular até 2050. Esse programa estabelece diversas metas, dentre as quais, a reutilização contínua de recursos, visando-se evitar justamente desperdícios. Ver: https://www.government.nl/topics/circular-economy Acesso em: 10 set. 2020.

16 A tese teve como objetivo principal investigar práticas alimentares de imigrantes transnacionais residentes em Amsterdã. Disponível em: https://repositorio.ufsc.br/xmlui/handle/123456789/178589

17 Tompson (2017) ainda observa que, em muitas sociedades não ocidentais, o valor atribuído aos itens é muito maior após serem descartados. 


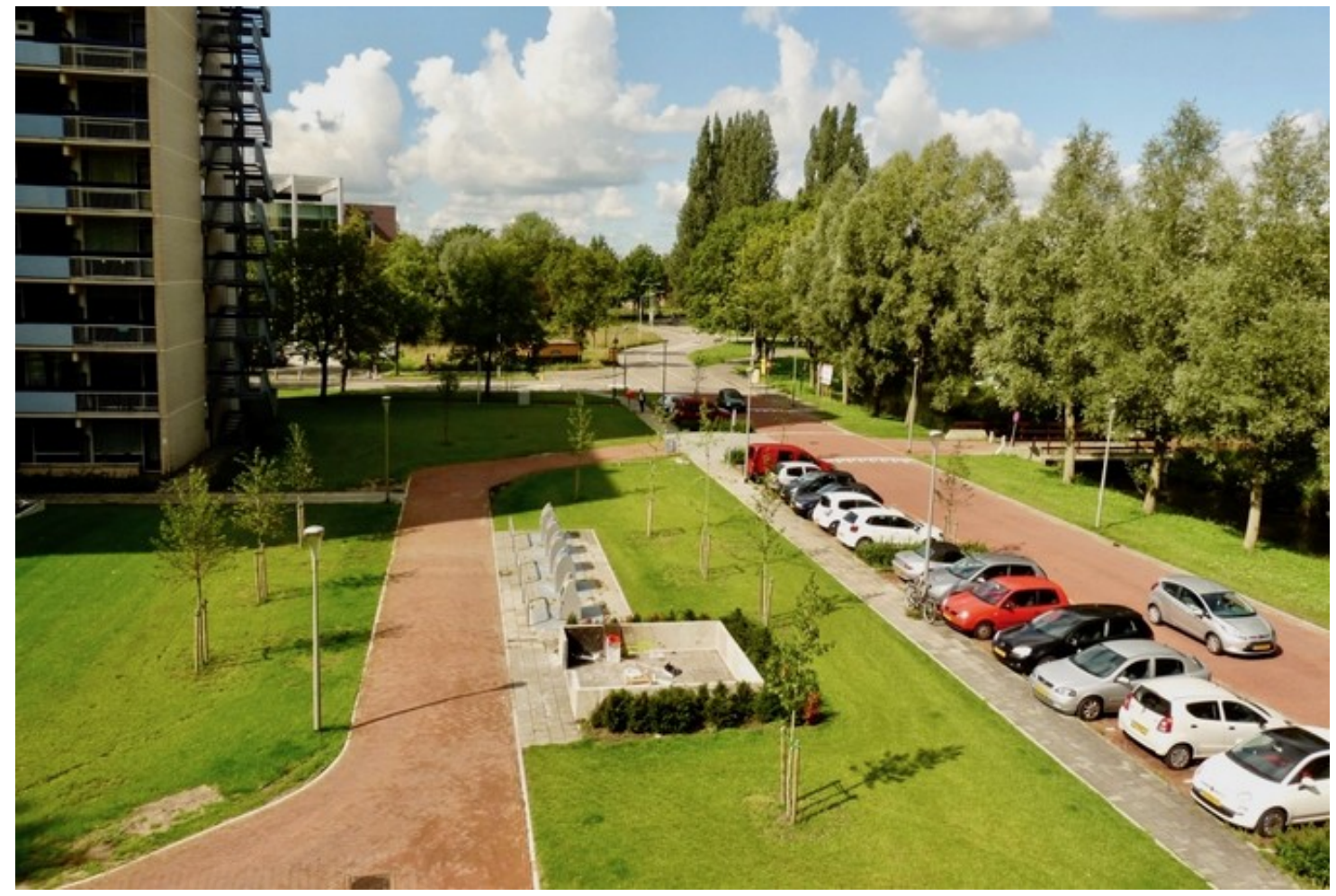

Imagem 1. Fonte: arquivo pessoal

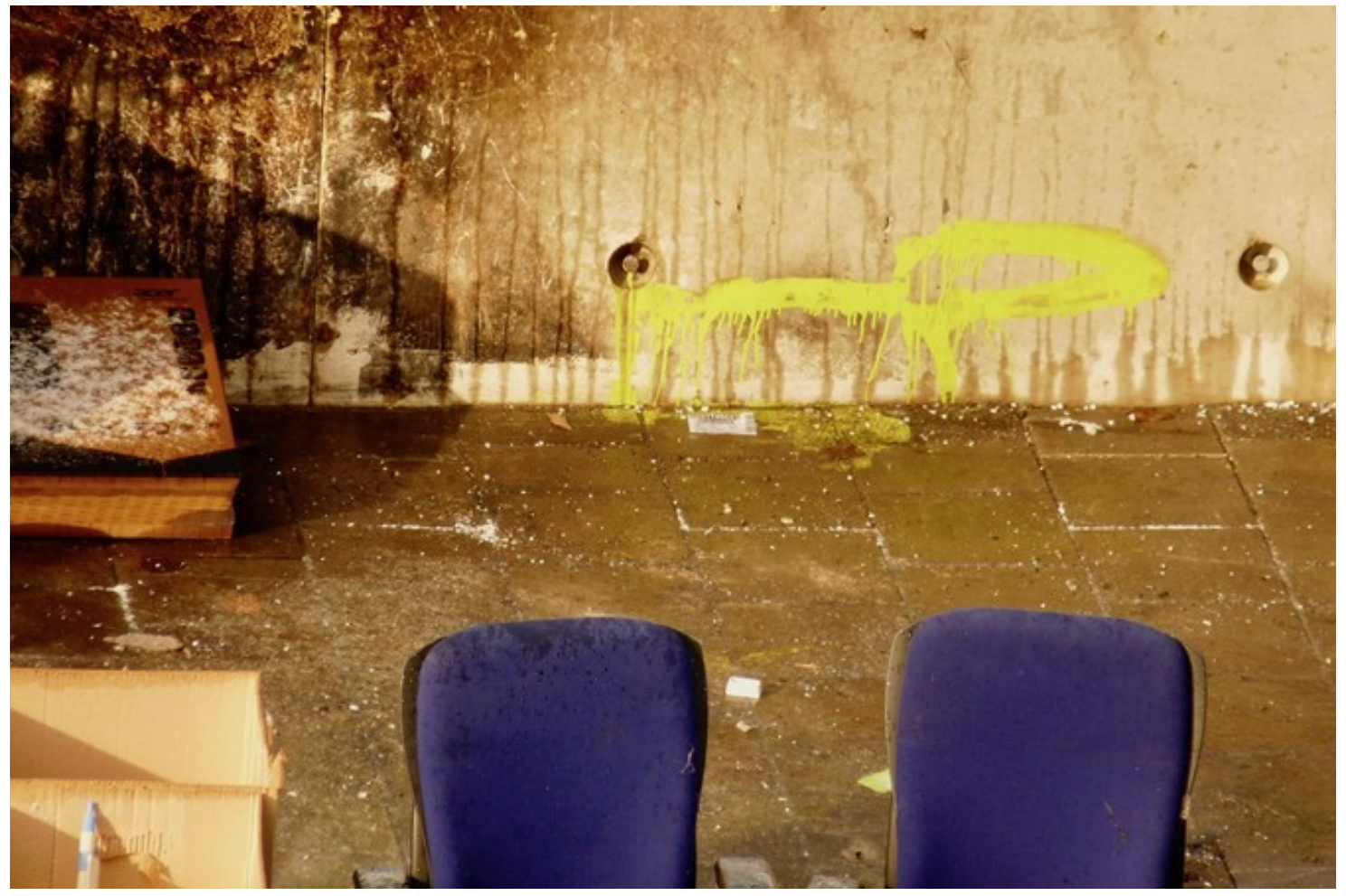

Imagem 2. Fonte: arquivo pessoal 


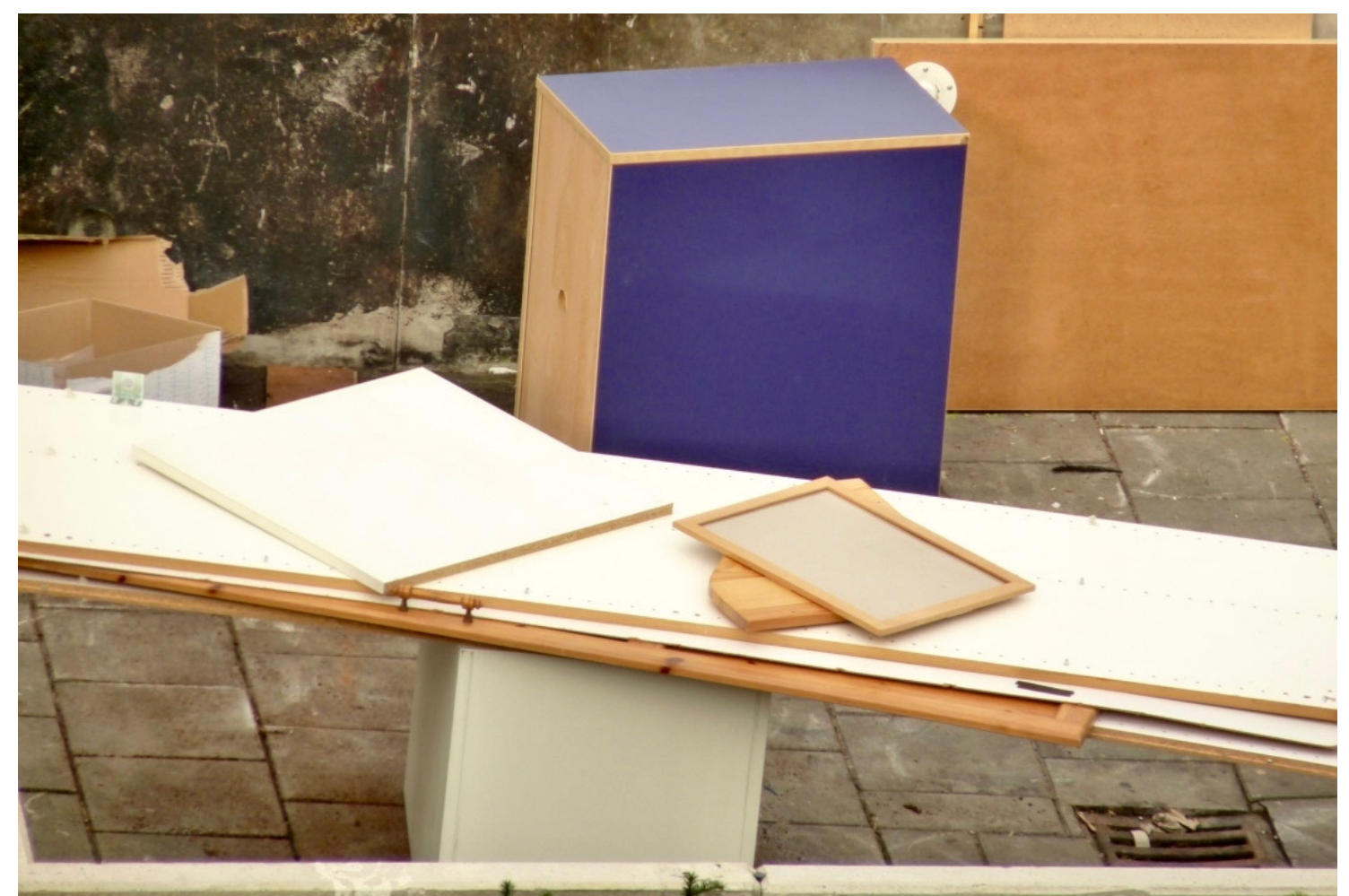

Imagem 3. Fonte: arquivo pessoal

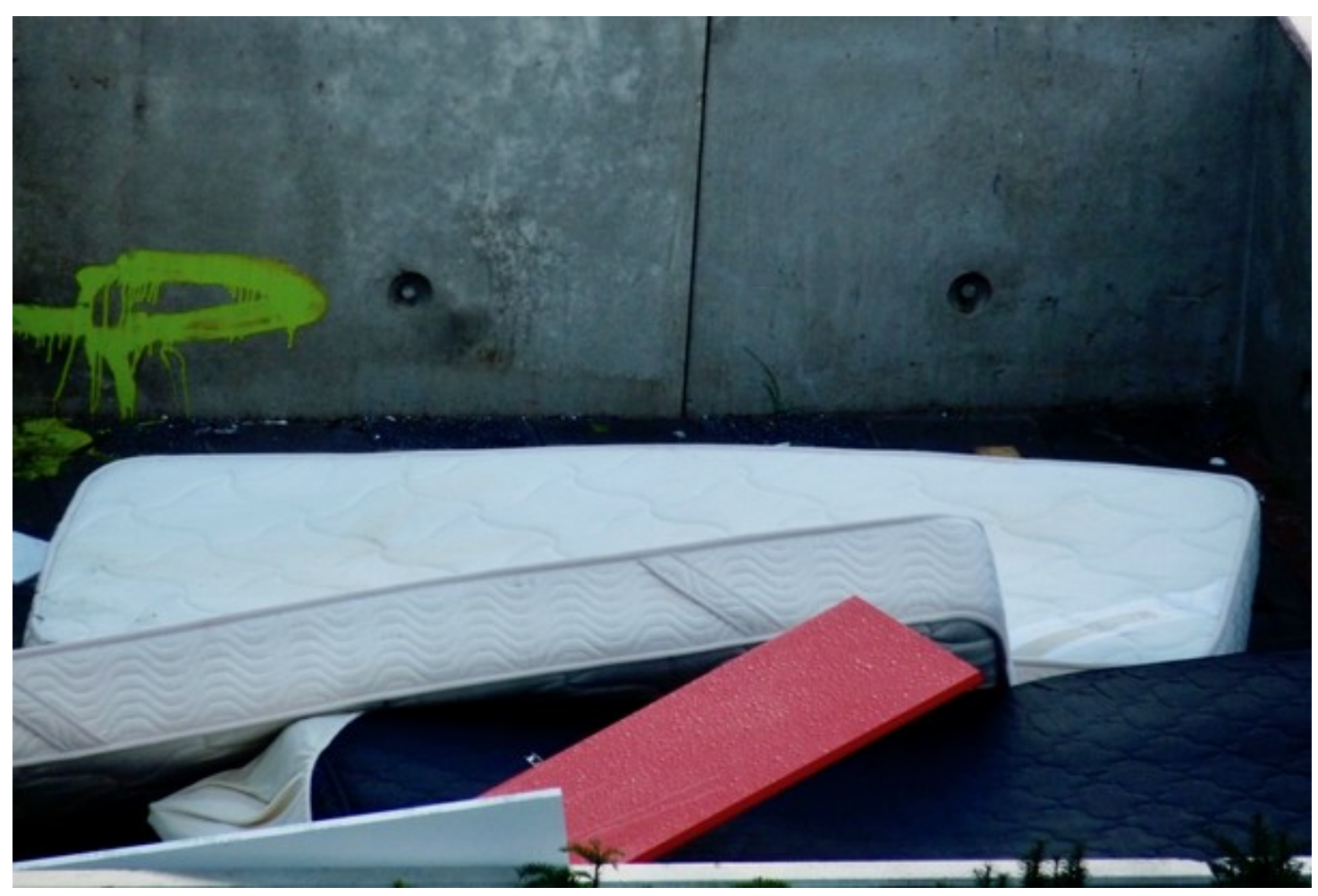

Imagem 4. Fonte: arquivo pessoal 


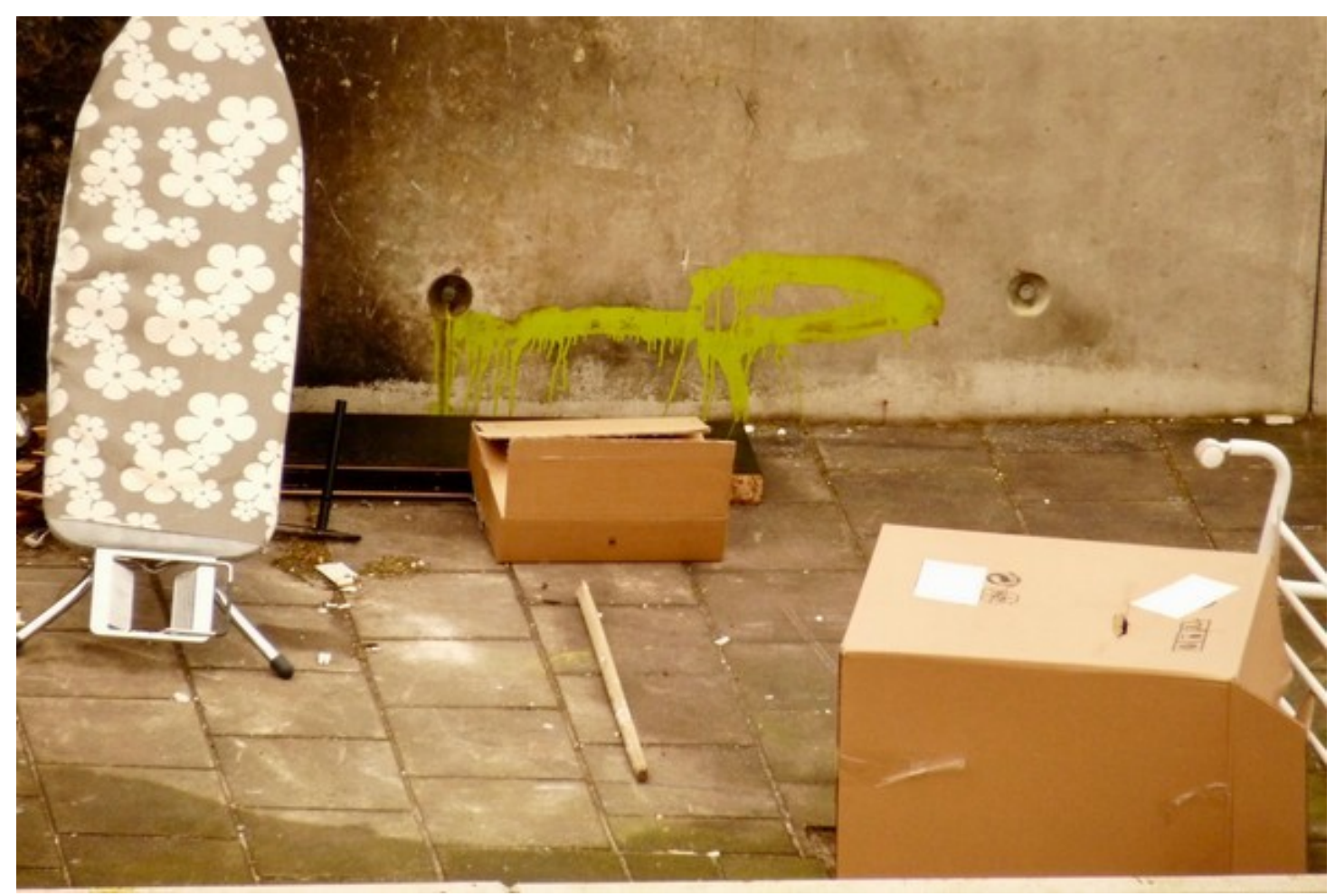

Imagem 5. Fonte: arquivo pessoal

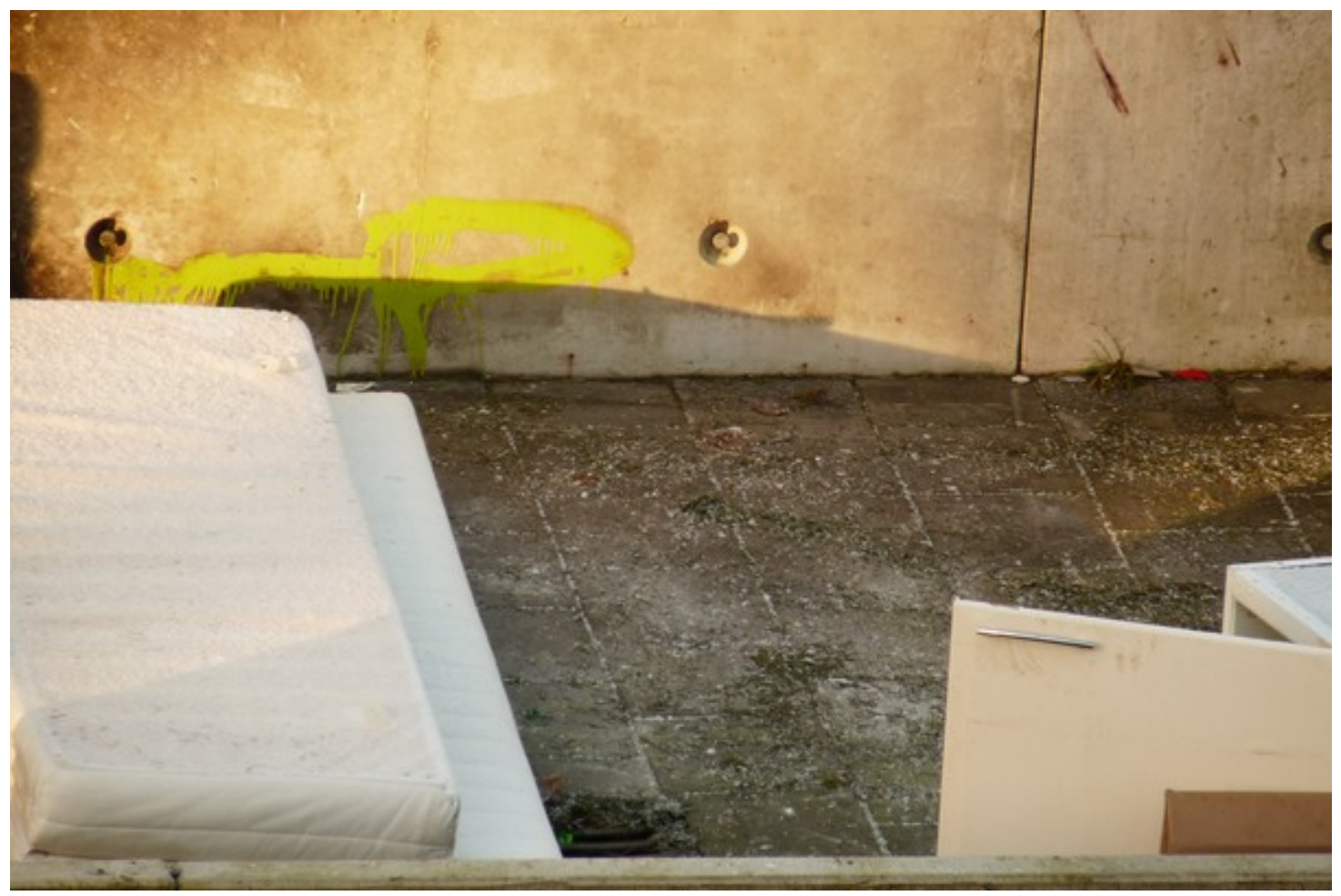

Imagem 6. Fonte: arquivo pessoal 


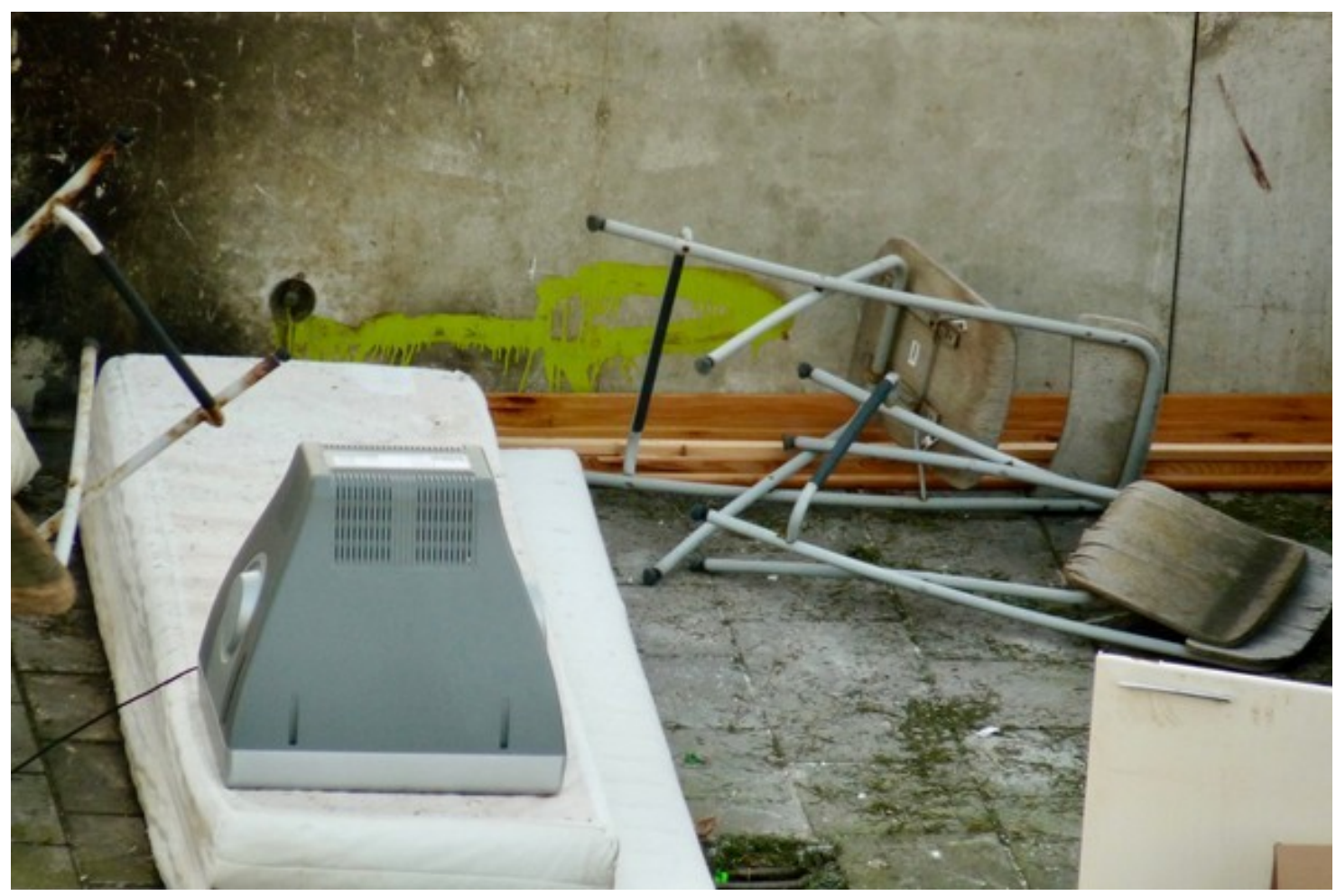

Imagem 7. Fonte: arquivo pessoal

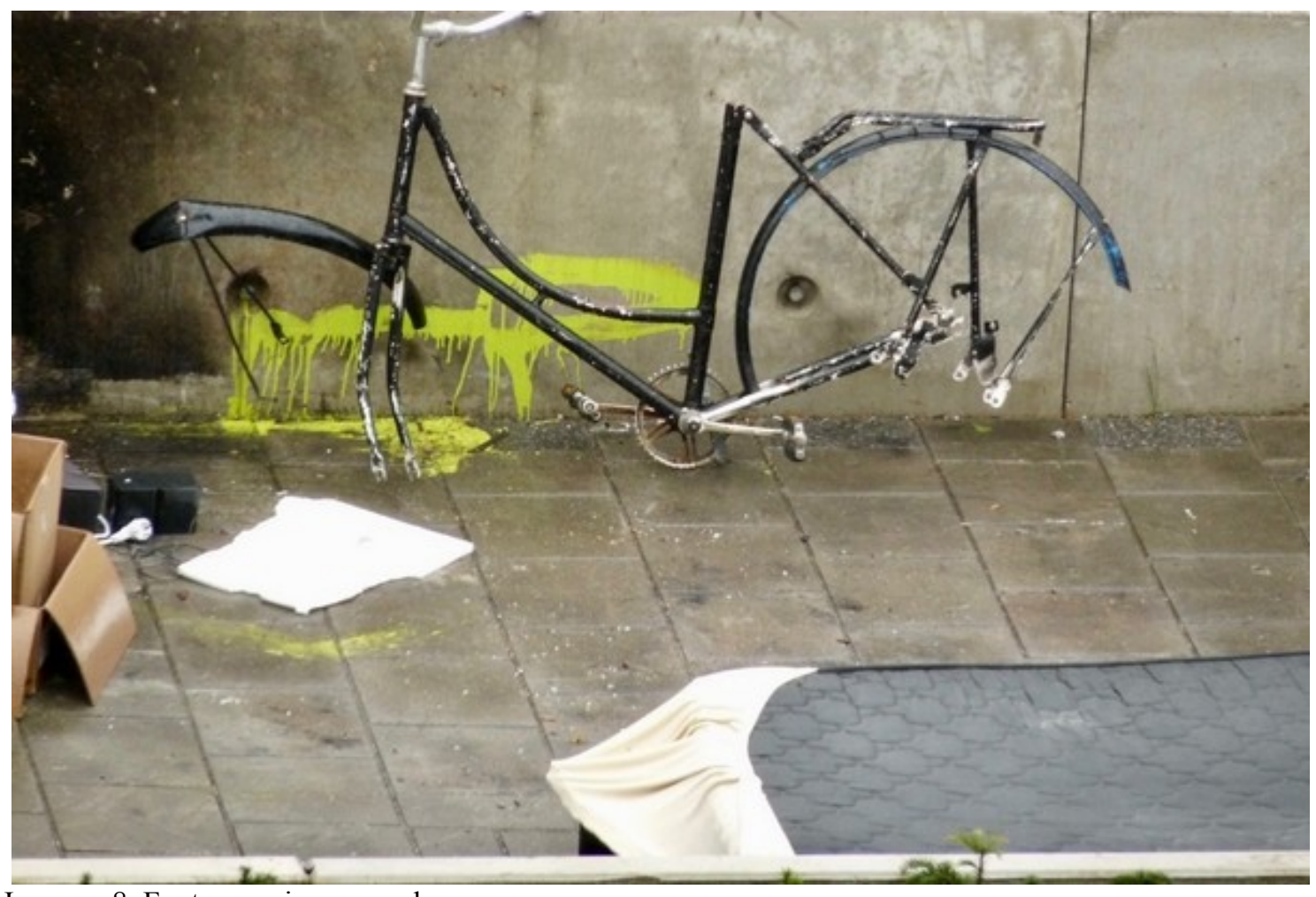

Imagem 8. Fonte: arquivo pessoal 


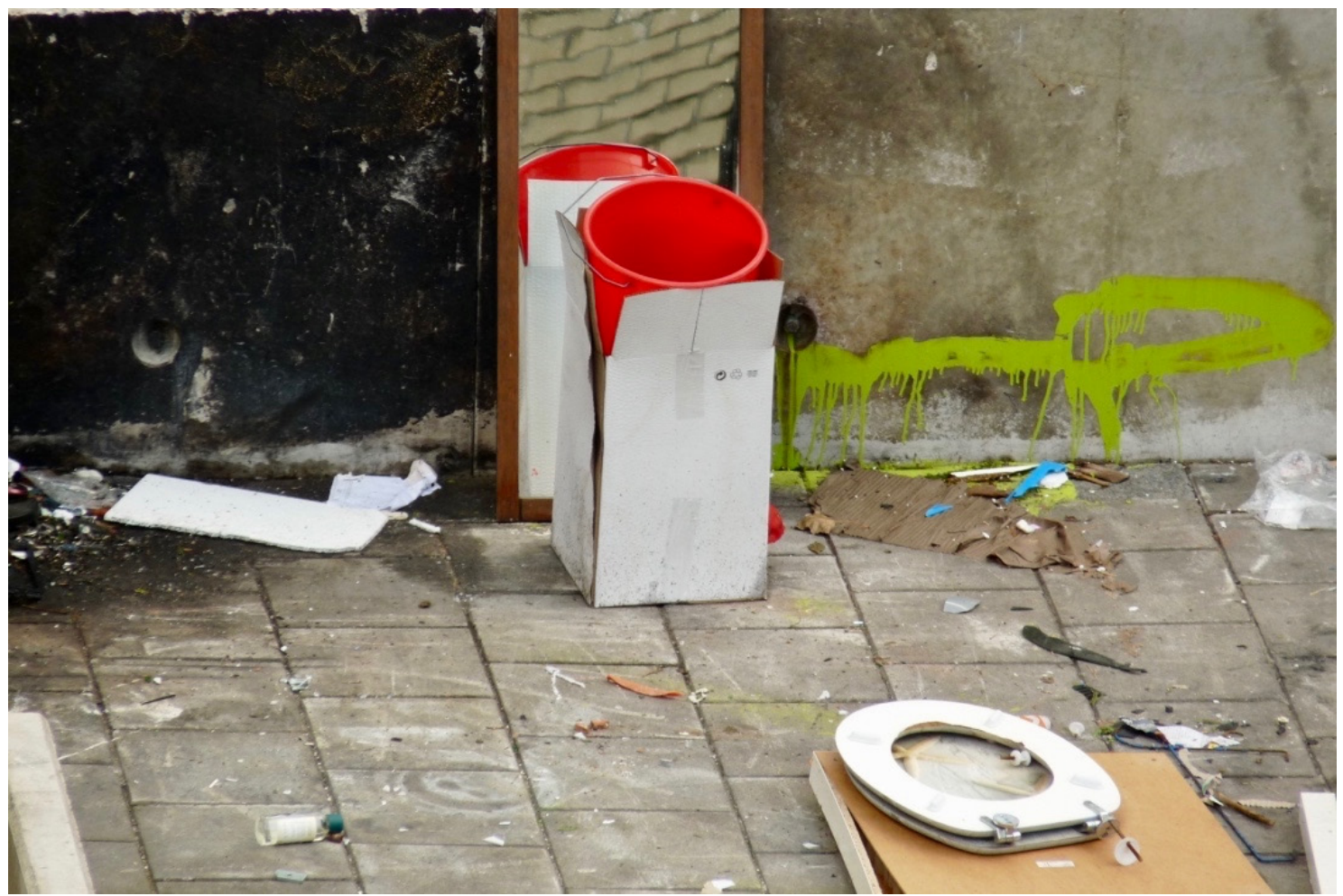

Imagem 9. Fonte: arquivo pessoal

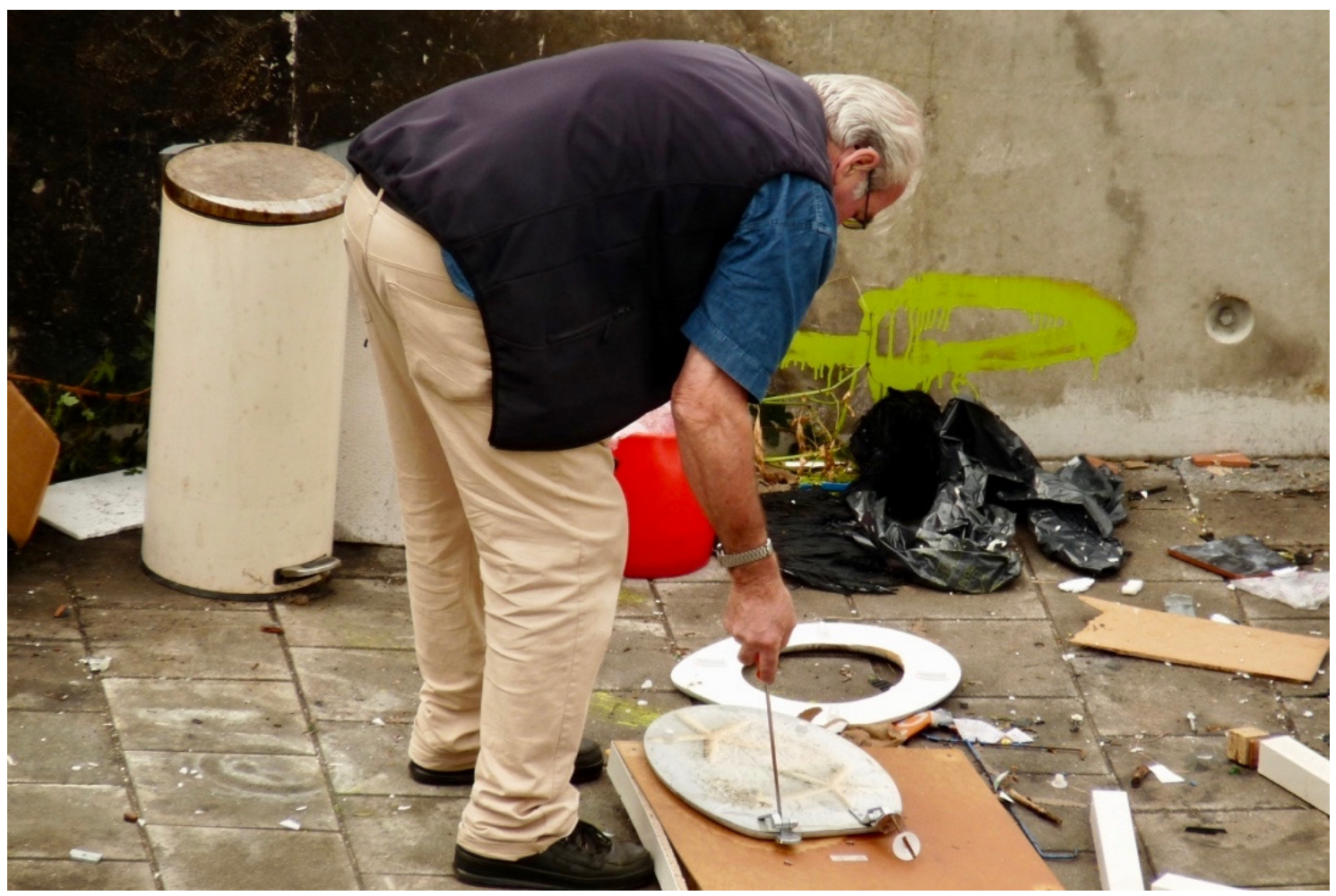

Imagem 10. Fonte: arquivo pessoal 


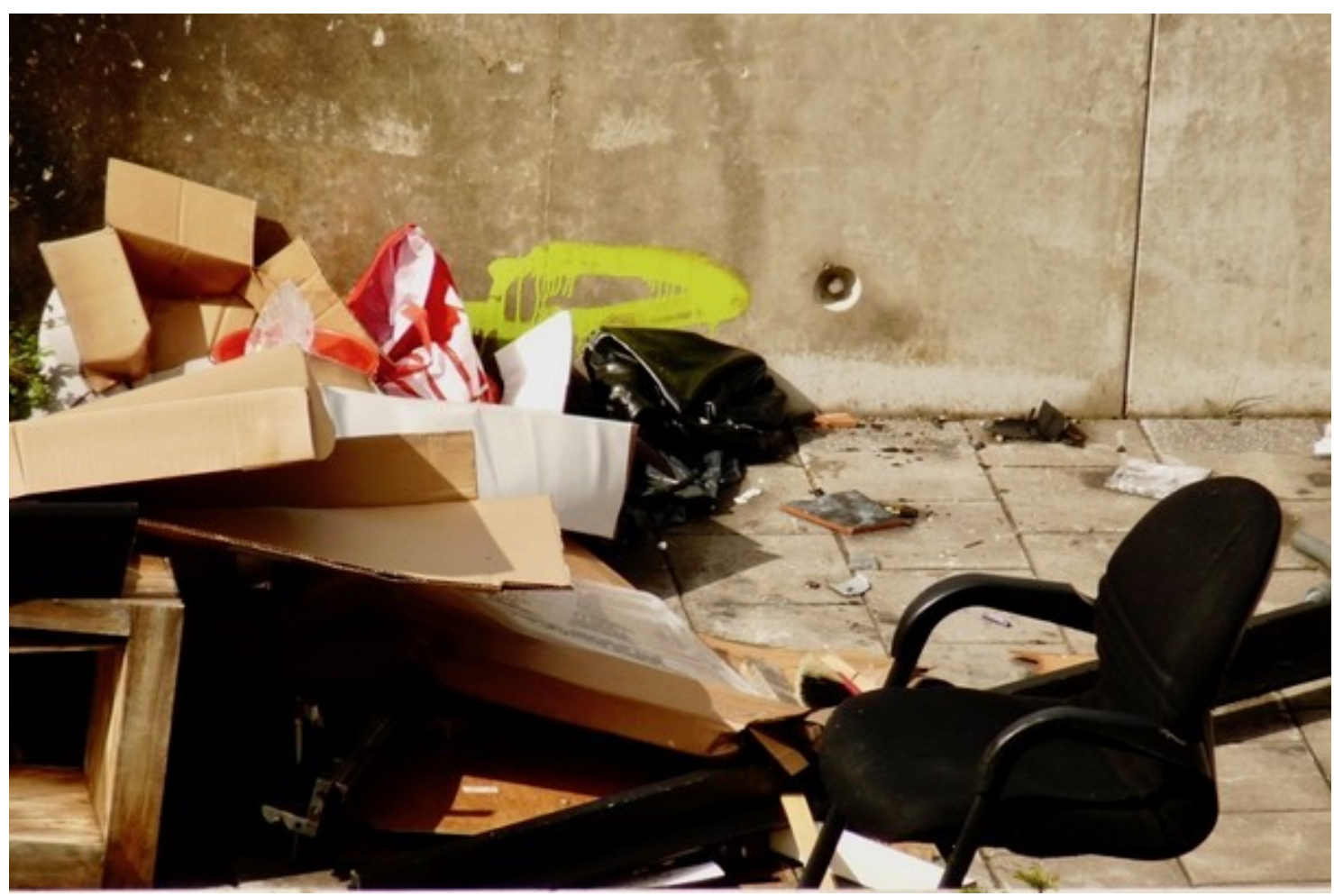

Imagem 11. Fonte: arquivo pessoal
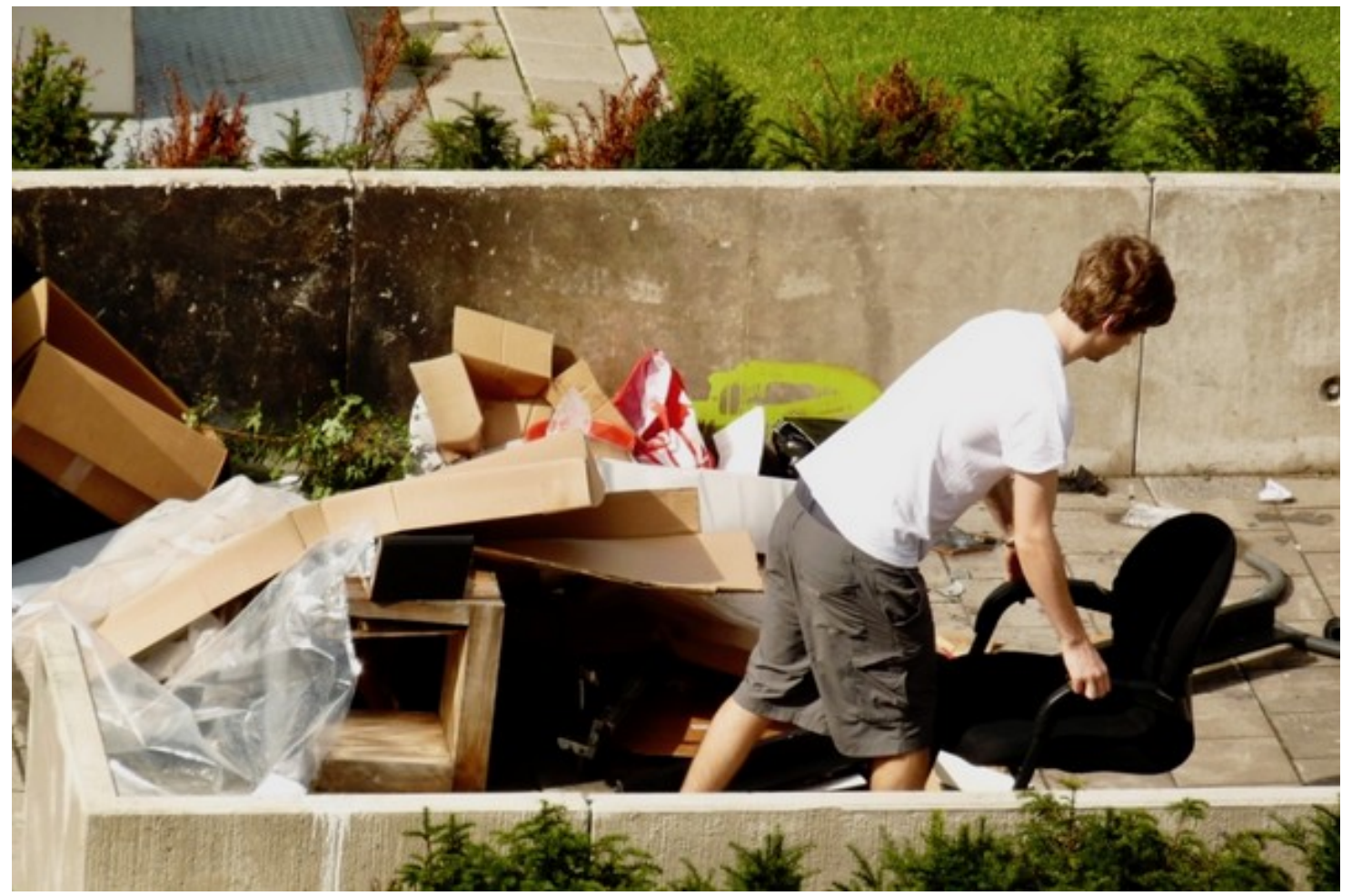

Imagem 12. Fonte: arquivo pessoal 


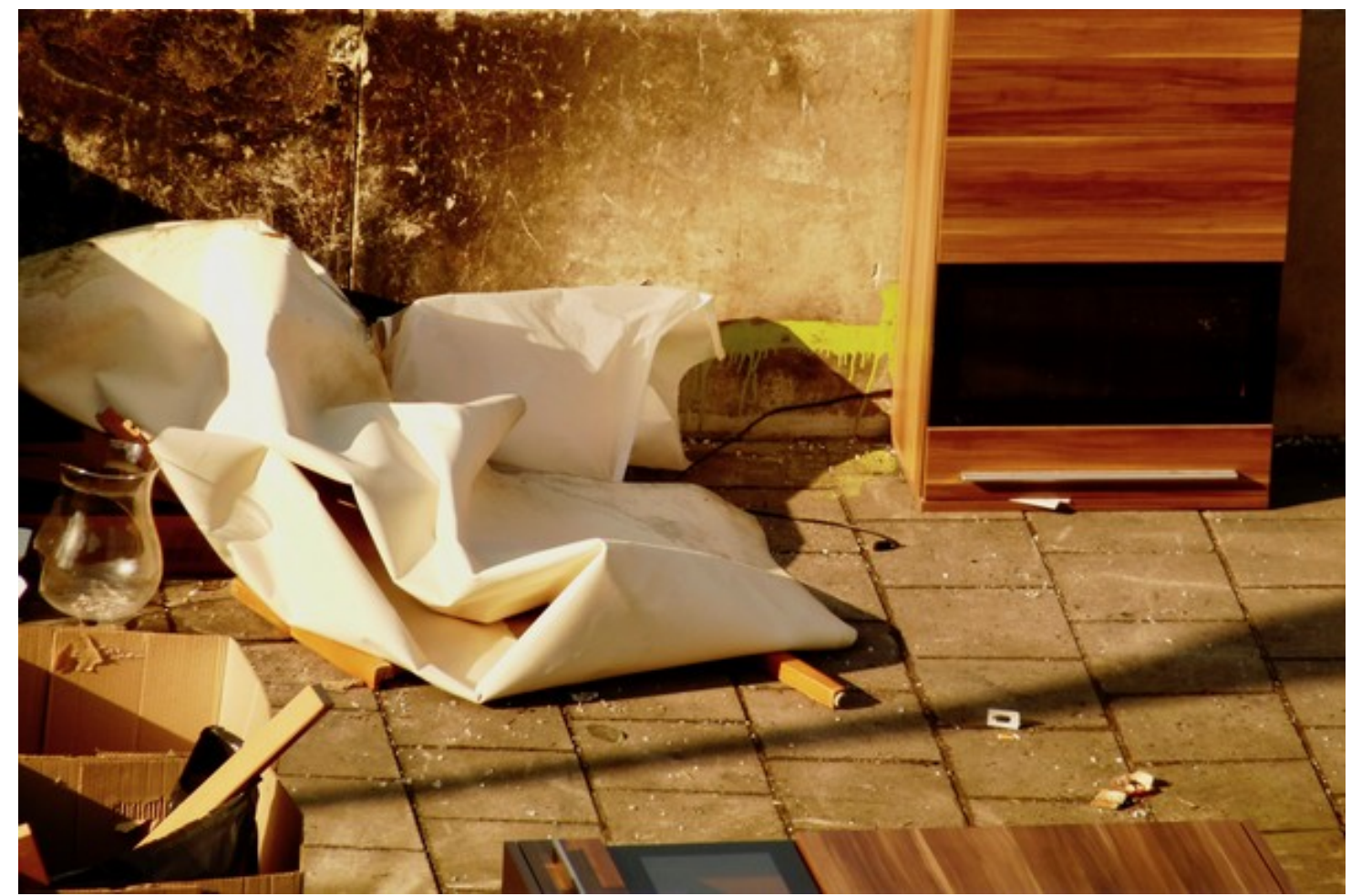

Imagem 13. Fonte: arquivo pessoal

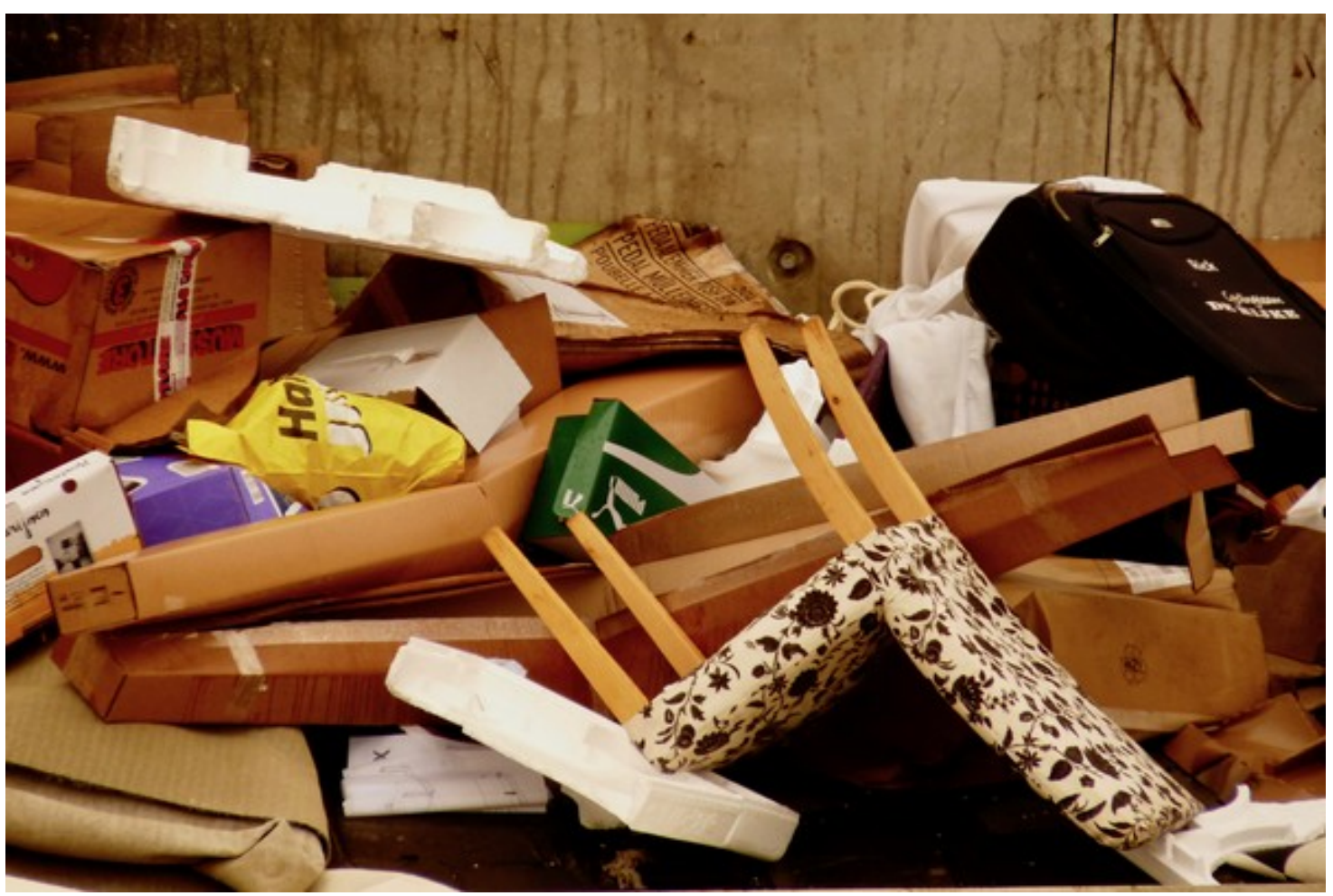

Imagem 14. Fonte: arquivo pessoal 


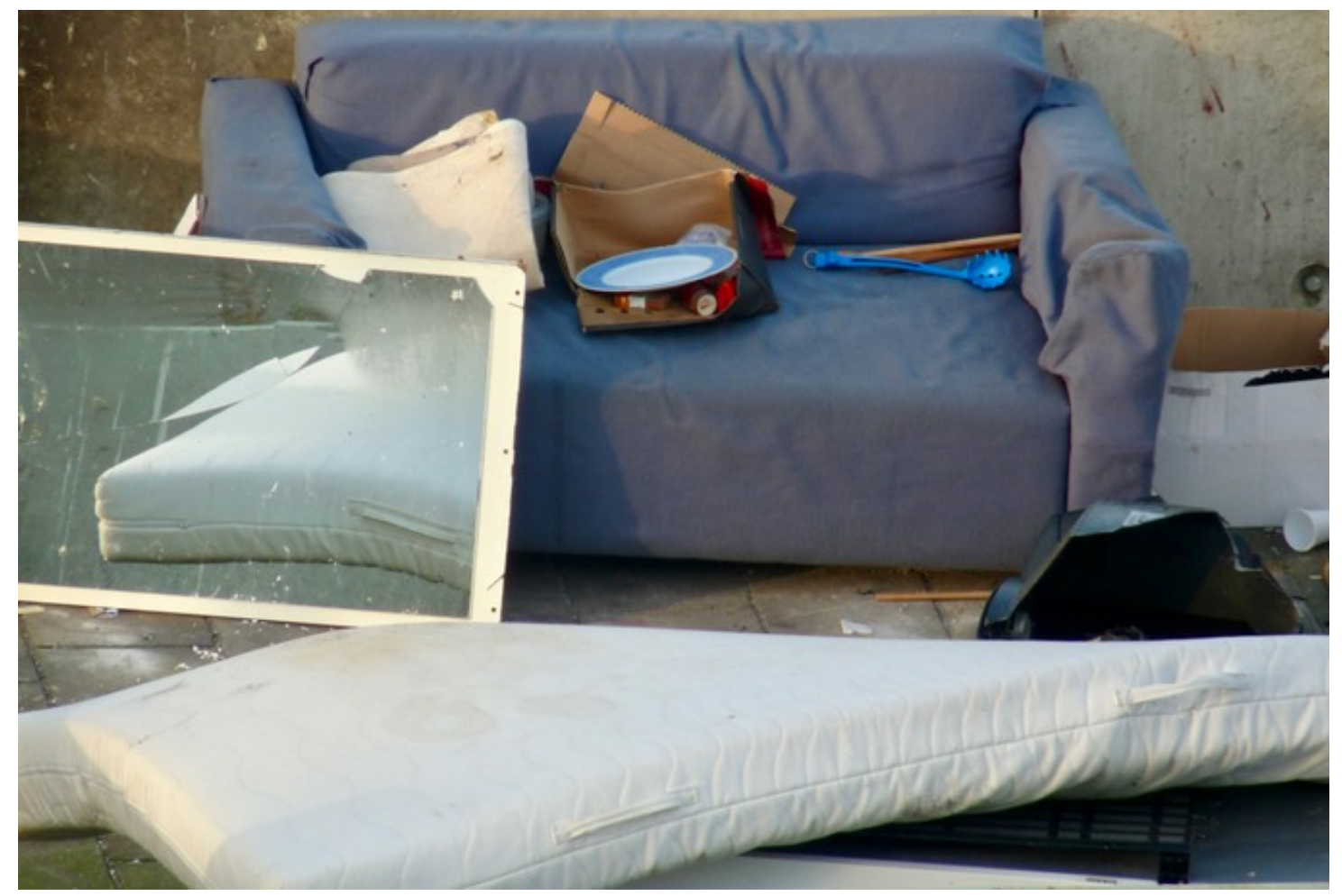

Imagem 15. Fonte: arquivo pessoal

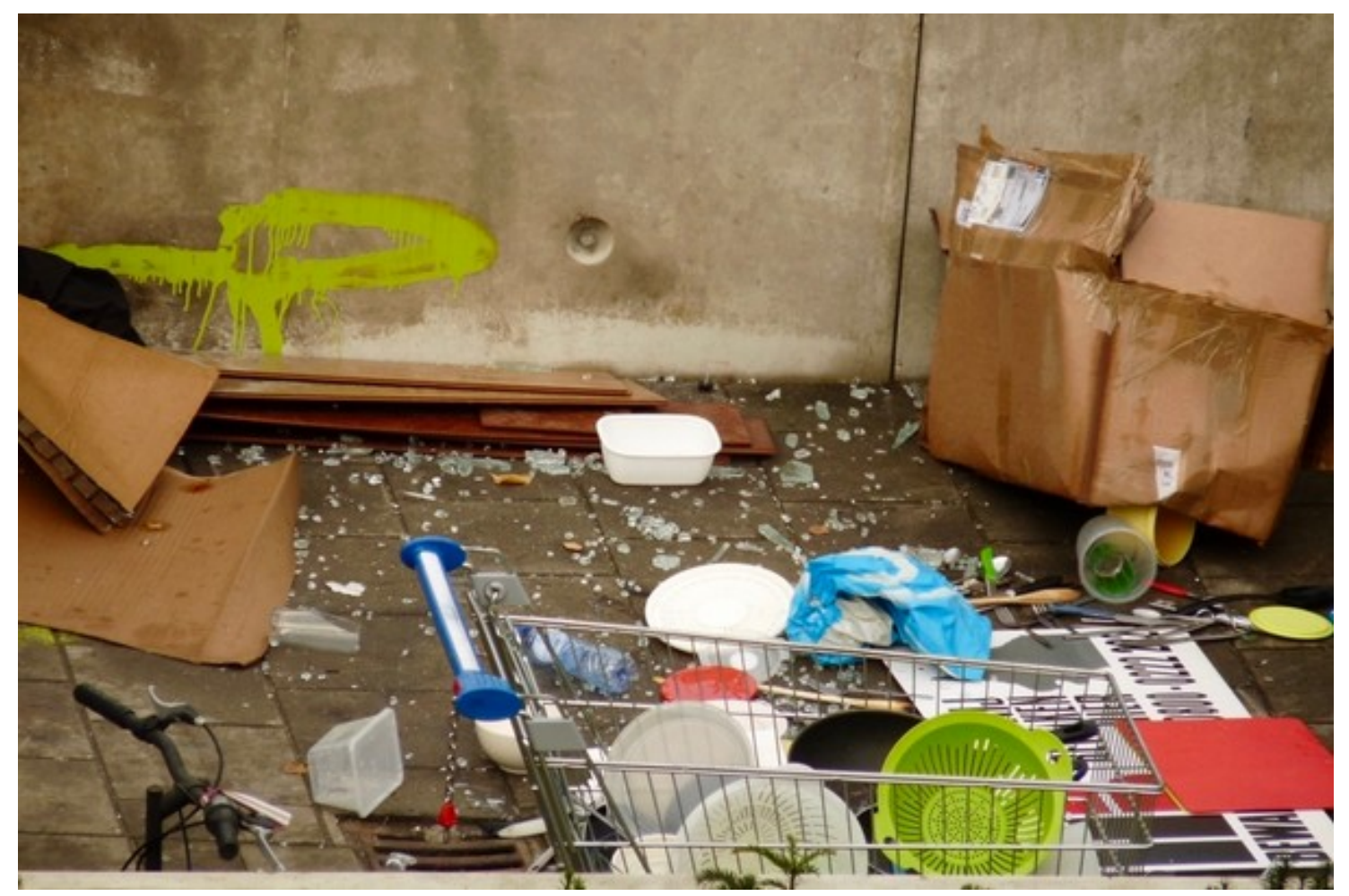

Imagem 16. Fonte: arquivo pessoal 


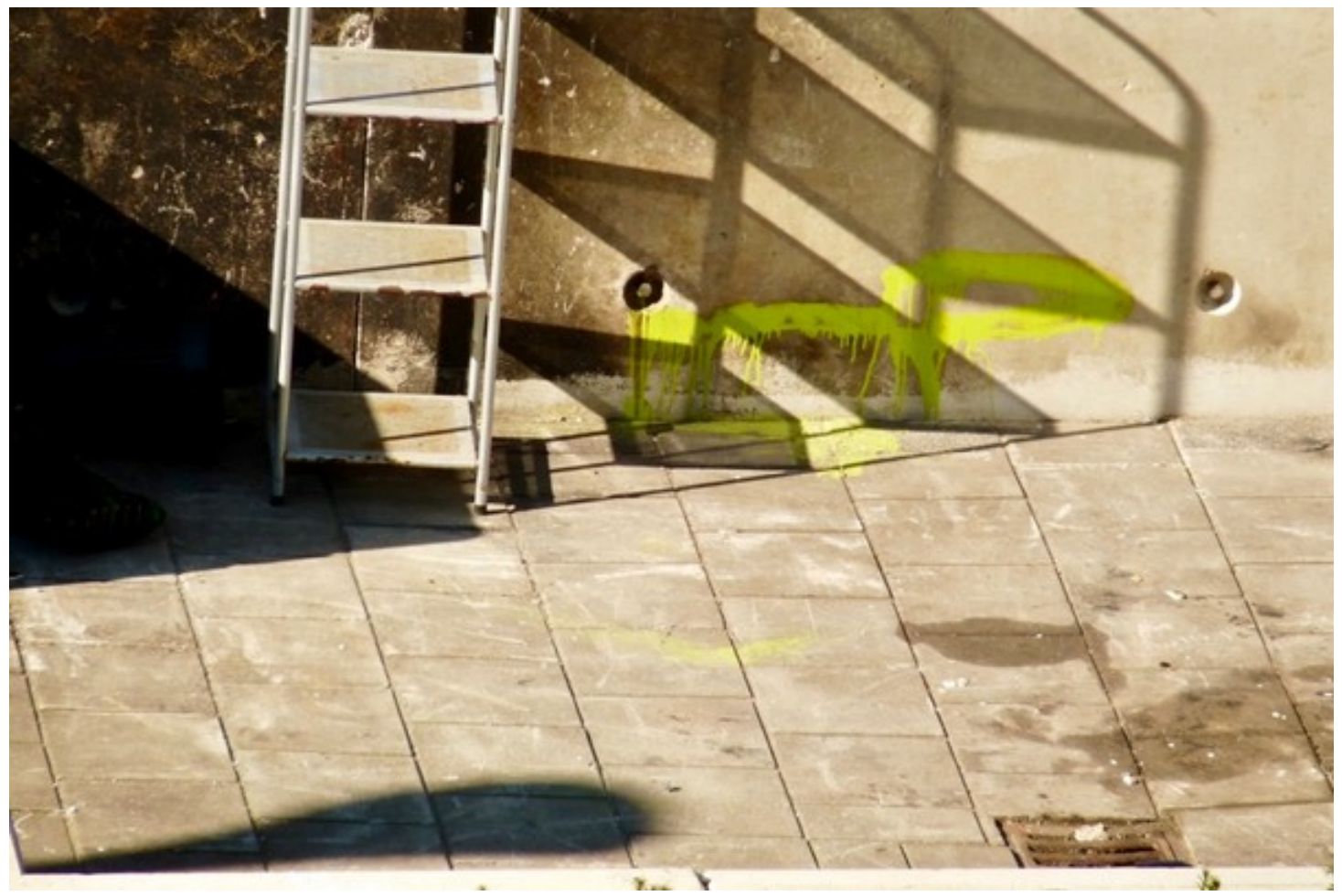

Imagem 17. Fonte: arquivo pessoa

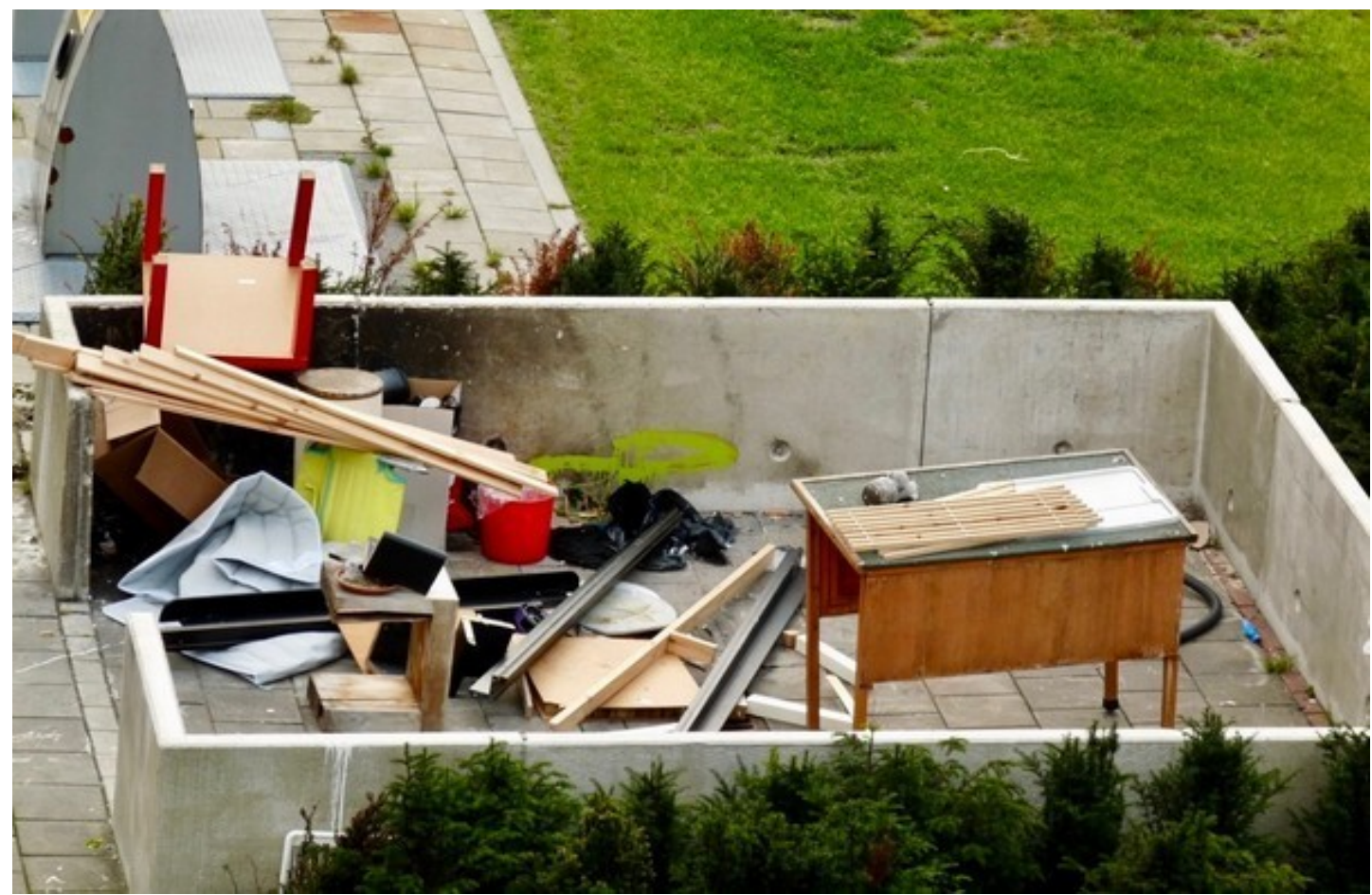

Imagem 18. Fonte: arquivo pessoal 


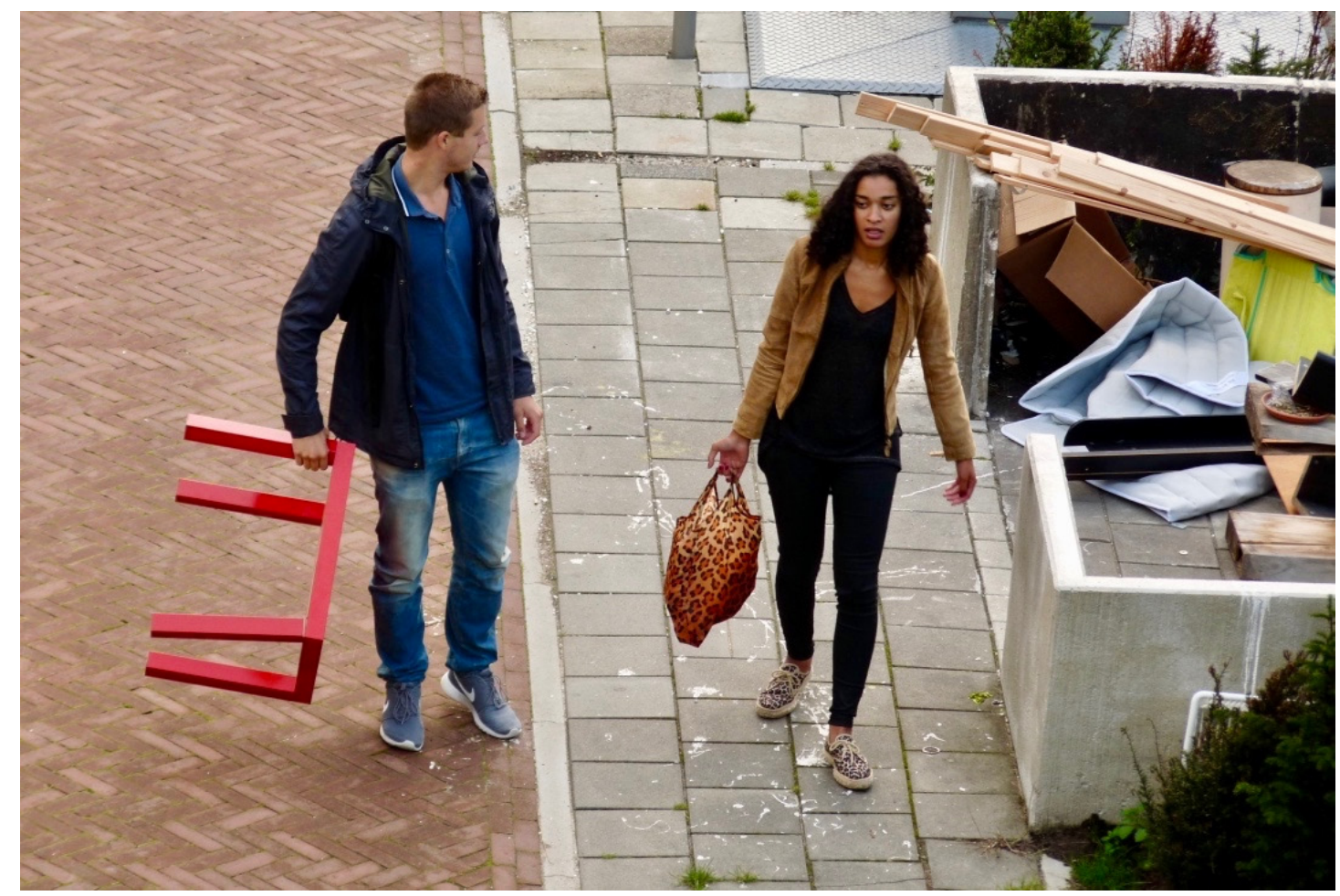

Imagem 19. Fonte: arquivo pessoal

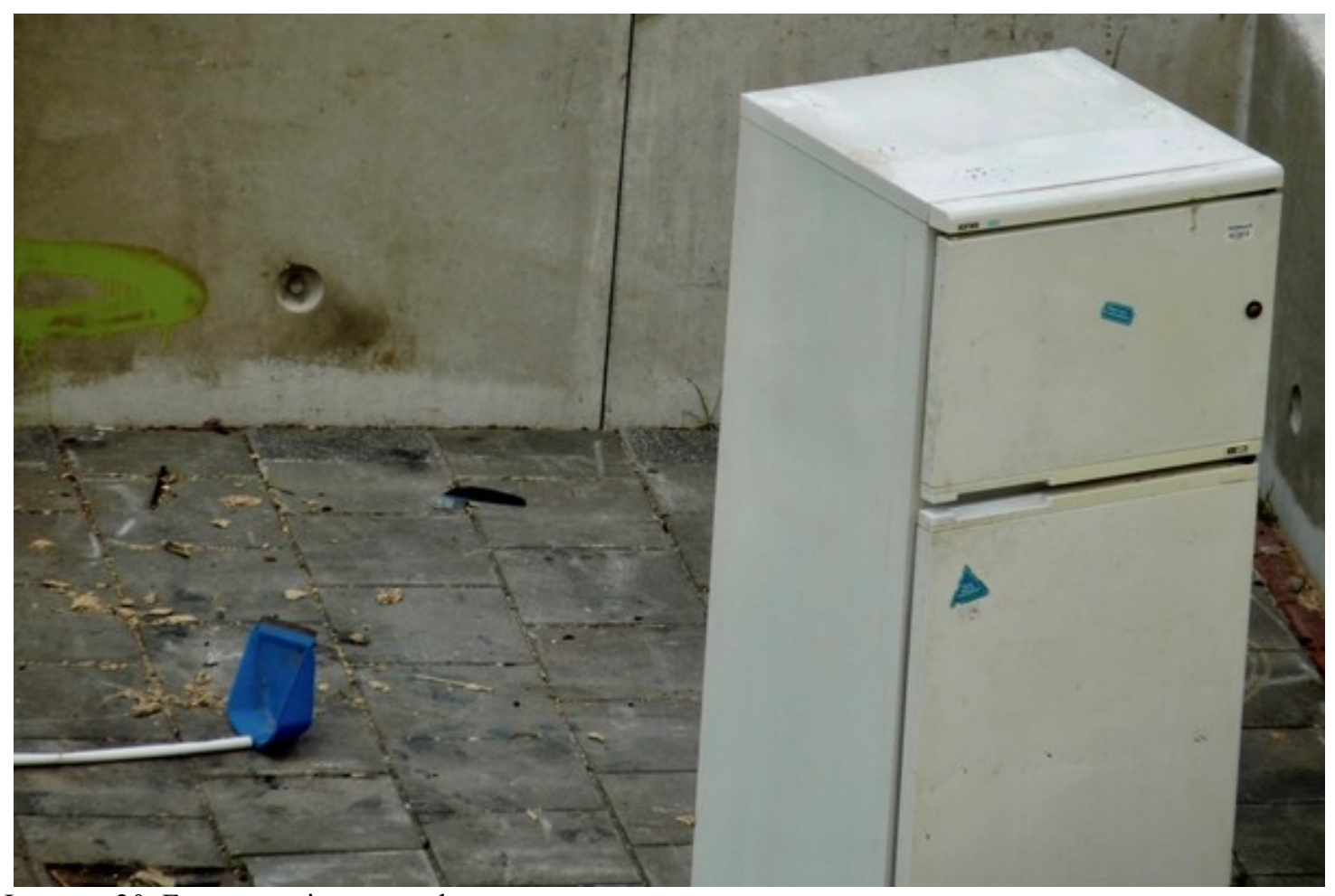

Imagem 20. Fonte: arquivo pessoal 


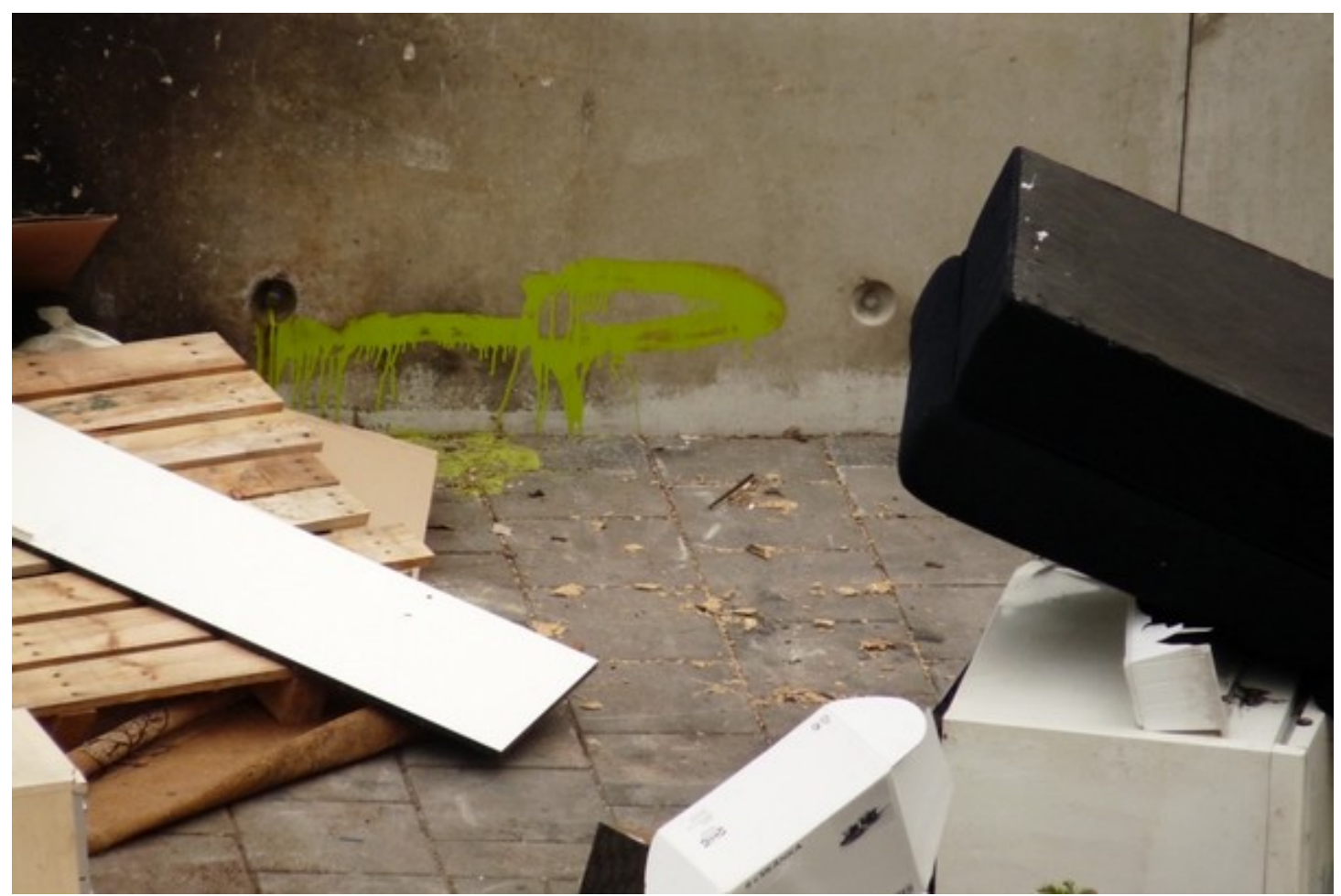

Imagem 21. Fonte: arquivo pessoal

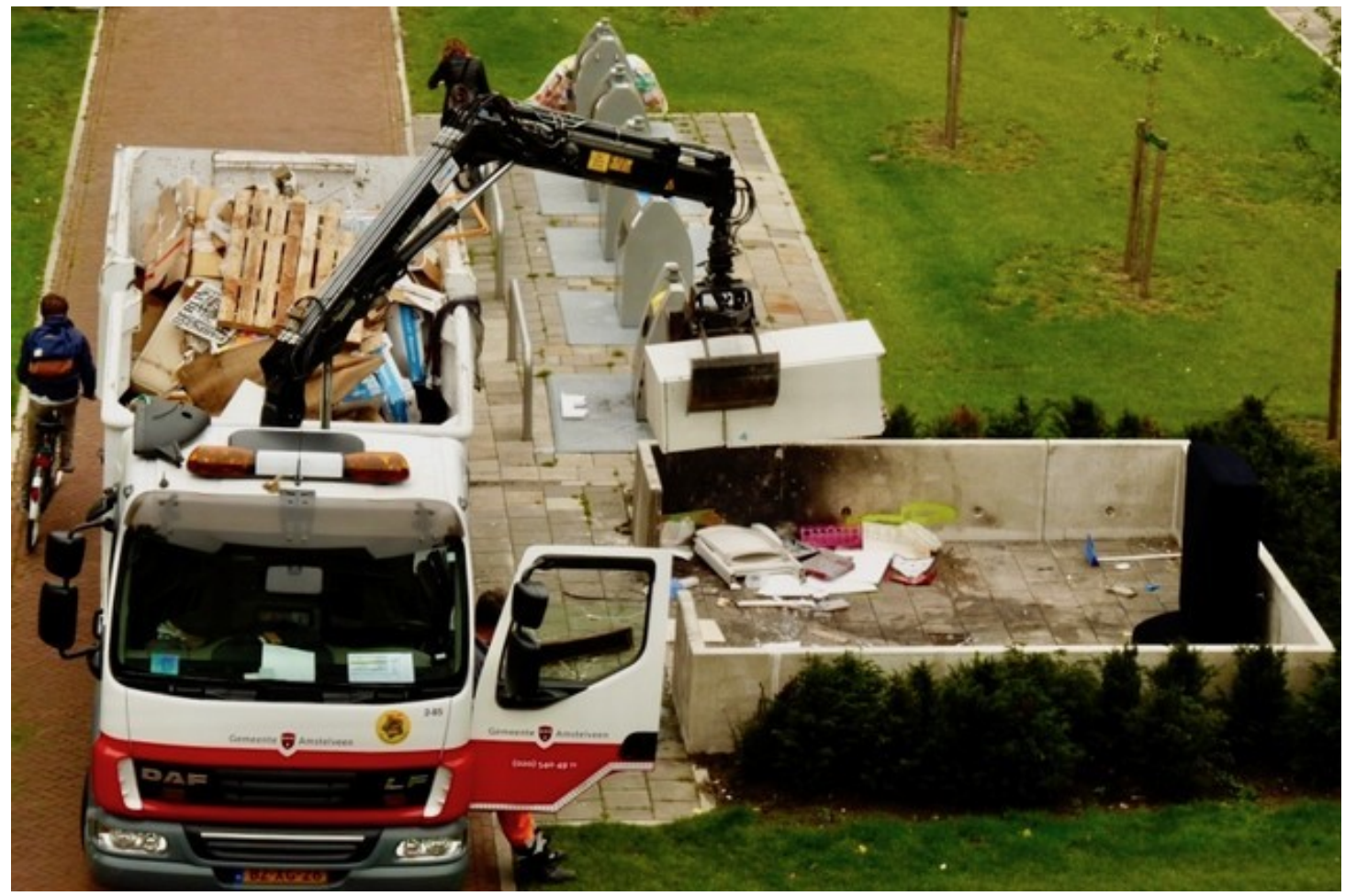

Imagem 22. Fonte: arquivo pessoal 


\section{REFERÊNCIAS}

APPADURAI, Arjun. Modernity at large: cultural dimensions of globalization. Minneapolis, Minn.: University of Minnesota Press, 1996.

. Introdução: Mercadorias e a política de valor. In: APPADURAI,

Arjun. A vida social das coisas: as mercadorias sob uma perspectiva cultural. Trad. Agatha Bacelar. Niterói-RJ: Editora da Universidade Federal Fluminense, 2008.

DOUGLAS, Mary. Pureza e Perigo. Ensaio sobre as noções de Poluição e Tabu. Lisboa: Edições 70, 1991.

DUBOIS, Philippe. Da imagem-traço à imagem-ficção: O movimento das teorias da fotografia de 1980 aos nossos dias. Tradução: Henrique Codato e Leonardo Gomes Pereira. In: Discursos fotográficos, Londrina, v.13, n.22, p.31-51, jan./jul. 2017.

CASTLES, Stephen; MILLER, Mark J. The age of migration: international population movements in the modern world. Londres, Nova York: MacMillan Press, 1993.

FERREIRA, Aurélio Buarque de Holanda. Novo dicionário da Língua Portuguesa. 2 ed. Rio de Janeiro: Editora Nova Fronteira, 1987.

HOUAISS, Antônio. VILLAR, Mauro. Dicionário Houaiss de Língua Portuguesa. Elaborado pelo Instituto Antônio Houaiss de Lexicografia e Banco de Dados da Língua Portuguesa S/C Ltda. Rio de Janeiro: Objetiva, 2009.

ROCHA, Carla Pires Vieira da. Comida em uma cidade global: práticas alimentares de imigrantes transnacionais em Amsterdã. Tese (Doutorado Interdisciplinar em Ciências 
Humanas) - Centro de Filosofia e Ciências Humanas, Universidade Federal de Santa Catarina, Florianópolis, 2017.

SCHIETTEKATTE, Nico; BAKKER, Ernst-Jan. Uma Holanda circular em 2050 In: LUZ, Beatriz (org.). Economia circular Holanda: Brasil: da teoria à prática. 1. ed., Rio de Janeiro : Exchange 4 Change Brasil, 2017. p. 03-09.

My first month: all you need to know and note. Expatcenter Amsterdam, 11 ed. Jan, 2015.

SASSEN, Saskia. Sociologia da globalização. Porto Alegre: Artmed, 2010.

THOMPSON, Michael. Rubbish Theory: The Creation and Destruction of Value. (2 ed.) London, UK: Pluto Press, 2017.

Recebido: $13 / 09 / 2020$

Aprovado: 08/12/2020 